\title{
FŐÚRI HÁZIKÁPOLNÁK A 18-19. SZÁZADI MAGYARORSZÁGON
}

\author{
FEKETE J. CSABA \\ PhD, okl. építészmérnök, müemlékvédelmi egyetemi szakmérnök, műemléki szakértő, egyetemi adjunktus. \\ BME Építészettörténeti és Műemléki Tanszék, 1111 Budapest, Müegyetem rkp. 3. K 282. \\ Tel.: (+36-1) 463-1330. E-mail: fekete@eptort.bme.hu
}

\begin{abstract}
A kastélyok, paloták, kúriák, „,várkastélyok”, várak - vagyis a foúri lakóhelyek - elsősorban profán építészeti müfajt képviselnek, azonban funkcionális sokszínűségüket és komplexitásukat jól reprezentálja, hogy többségük szakrális rendeltetéselemeket is befogadott. A házikápolna a világi föúri lakóhelyekben az otthoni vallásgyakorlás legfontosabb színhelye, amely a 19. század közepéig jellemzően a fóúri vallásosság szimbóluma volt. A házikápolnák térkompozíciója a liturgia egyszerüsített változatára specializálódott. Ugyanakkor a foóri, valamint a köznépi együttes jelenlét funkcionálisan differenciált, tagolt téralakítást eredményezett. A 18. századi példák nagy belmagasságú, karzatokkal kialakított, boltozott csarnokterei késő középkori hagyományon alapulhattak, ugyanakkor korabeli jellemzöjük, hogy közvetlen udvari bejáratuk révén nyilvános liturgiára is alkalmasak voltak. A házikápolnák diszpozíciója a 18-19. században rendkívüli változatosságot mutatott. Az 1850 előtti példáknál az épületen belüli térkapcsolatot a föúri oratórium-karzat biztosította, amely jellemzően a férfi lakosztály felöl - annak földszinti vagy emeleti elhelyezésétől függetlenül - volt megközelíthető. Az időszakban volt példa arra, hogy a kápolna a női oldalon helyezkedett el, és volt példa a két lakosztály közötti diszpozícióra is. A nagyvonalú, attraktív kialakítású nyilvános kápolnák mellett kisebb, helyiségsorba illeszkedő, lakosztályokon belülre pozícionált magánkápolnát is gyakran létesítettek a korszakban. A 19. század közepétől a házikápolnák hagyományos funkcionalitása megmaradt, de elhelyezésükre jellemző volt a tulajdonosi lakosztályoktól távolabbi, esetenként a vendéglakrészekhez az épületszárnyak végén kapcsolódó, tehát az elsődleges forgalmi terektől kieső, ,perifériás” diszpozíció, de előfordult a központi társasági terek monumentális csoportjához történő hangsúlyos kapcsolódás is.
\end{abstract}

Kulcsszavak: kastély, palota, foúri lakóhely, házikápolna, magánkápolna, oratórium, funkció, diszpozíció, barokk, historizmus

\section{A FÖÚRI VALLÁSOSSÁG JELLEMZÖI 1600 UTÁN}

Napjaink rétegszociológiai kutatásai alátámasztják azokat a 20. századi vizsgálati eredményeket, amelyek szerint a történelmi arisztokrácia, különösen a fönemesség meggyőződésből eredő, mély vallásossága összekapcsolódik a föúri neveltetés sajátosságaival, különösen a keresztény hit átadásának fontosságával. A vallásosság az arisztokrácia körében még 1945 után, a vallási hanyatlás legeröteljesebb korszakában is sokkal erősebben megmaradt, mint más társadalmi rétegekben. A mai Magyarországon élő főnemesi származású - többségében római katolikus vallású - keresztények hitét elsősorban az egyéni útkeresésük erősítette meg, amely a többségüknél alapvető szerepet játszik; a hit központi helyet foglal el az üdvözülés reményével. 
Mások számára a vallás elsősorban az erkölcsi értékrend megformálásában segítő tényező. A korábbi generációk esetében viszont részben a vallásos nevelés, az egyházi iskolákban nyújtott kitünő oktatás játszhatott alapvető szerepet a hit megtartásában annak ellenére, hogy a vallásosság diszkrimináló tényezőként szerepelt az egyéni életutakban. A második világháború előtt a főnemesek az elemi négy osztályát általában magántanulóként otthon végezték házitanítók segítségével. A foúri gyermekek nevelésében jelentős szerepet játszott a piarista rend, számos piarista foglalkozott a magyar föúri családoknál nevelöi és titkári teendőkkel. Például a Festetics-család nevelője Nagy Jeromos piarista szerzetes volt, Bánffy György gyermekeinek nevelöje Bolla Márton, Széchényi Ferenc nevelője és titkára Pállya István szintén a piarista rendhez tartozott. Emellett a piarista rend széles körben foglalkozott a fönemesi konviktusok növendékeinek oktatásával. ${ }^{1}$ Középiskolába a főnemesi származású ifjak Magyarországon főleg az egyházi rendi gimnáziumokba - szintén a piaristákhoz vagy a bencésekhez, a cisztercitákhoz, a premontreiekhez, a jezsuitákhoz - jártak, Ausztriában pedig például az elegáns, nagy múltú bécsi Theresianumba. Akik felsőfokú tanulmányokat végeztek, azok elsősorban mezőgazdászok vagy jogászok lettek. A pesti egyetem filozófiai vagy jogi fakultása különösen látogatott volt a fönemesség körében. Az egy-két éves külföldi tanulmányút fontos része volt iskolázottságuknak. ${ }^{2}$

Alig egy évvel az 1608. évi országgyülés után, gróf Thurzó György (1567-1616), az új protestáns nádor jelentős engedményeket tett a katolikus egyháznak. Egyes főurak áttértek a katolikus hitre és birtokaikon hatalmi eszközökkel hajtották végre az ellenreformációt. A katolicizmus tudta a legsikeresebben engedelmességre nevelni híveit, sőt a túlvilági boldogság reményében helyzetük elfogadására, az abban való megnyugvásra szoktatta őket. A katolikus vallást mindvégig megtartó néhány arisztokrata család, a Pálffyak, Erdődyek, Draskovichok mellé az 1610-es években már egyre többen sorakoztak: a Homonnaiak, Forgáchok, Zrínyiek és később a Batthyányak, Nádasdyak. A leglátványosabb pályát ezekben az évtizedekben az az Esterházy Miklós (1714-1790) gróf futotta be, aki a legtudatosabban kapcsolta egybe a rendi és osztályérdekeket a megújuló katolicizmussal. ${ }^{3}$

A 17. század végétől kezdve a főnemesi réteg volt az a közvetítő, amelyen keresztül eljutottak hazánkba is az új teológiai-filozófiai eszmeáramlatok, közöttük a vallásos kegyesség személyesebb formáit hirdető irányzatok. Ilyen volt például az egyház szervezetének merevségén oldani kívánó katolikus (Cornelius Jansen holland teológus nevéből eredő) janzenizmus, melynek egyik hazai képviselője II. Rákóczi Ferenc (1676-1735) erdélyi fejedelem és birodalmi herceg volt. A korszakban elképzelt „udvari nemes ember”, az emberséges ember (honnête homme) jellemvonásai közt első volt a keresztény kegyesség, a bensőséges vallásosság. A felvilágosodás eszméi a főnemesség képviselői között találtak először követőkre. A foúri magánnevelés volt az, amely elsősorban követte a nyugat-európai példákat. Ennek nyomán a korábbi

\footnotetext{
${ }^{1}$ Németh 2005; Püski 2008; Balázs-Kézdy 2001; Sztárayné 2001. 84-91.

${ }^{2}$ Gudenus-Szentirmay 1989. 158-159.

${ }^{3}$ R. Várkonyi.
} 
latinos-humanisztikus-retorikus képzés új elemekkel gazdagodott a korszakban: az élő idegen nyelv elsajátításának, valamint az anyanyelv (az „úri” magyar nyelv) tanulmányozásának az igénye jelent meg; továbbá ekkorra tehető a történelmi-földrajzi ismeretek és a közéleti-társasági életben hasznos ismeretek integrálása a képzés repertoárjába. ${ }^{4}$

A protestáns förendi családoknál a vallásos nevelés a felvilágosodás idején nem volt szigorú. A szülők nem ismertették meg gyermekeiket a Bibliával, nem tanítottak nekik templomi énekeket, imákat. A vasárnapi istentiszteleten való részvétel szinte ismeretlen volt a számukra csakúgy, mint a napi imádkozás. A vallás a neveltetésen keresztül tehát nem hatott a gyermekek szellemiségére. A változás csak az 1820-as években, a pietizmus újjászületésével következett be, és ezután a vallási szellem és indíttatás ismét otthonra talált a protestáns fönemesek körében, és a nevelésben is visszanyerte a korábban elveszített magas presztízsét.

Ugyanakkor a katolikus fönemességet a 18-19. században ilyen jelentős változások nem jellemezték. A felvilágosodás gondolatrendszere az ő esetükben is a szigorú vallási eszmék fellazulását eredményezte, azonban nem járt a vallási szabályok teljes visszautasításával, hanem a keresztény szellemiség az egész korszakban áthatotta és meghatározta a nevelés rendszerét. ${ }^{5}$

A 18. század elejéig a magyarországi főnemesség férfi tagjai számára a vallás meghatározóbb tényező volt, mint nyugat-európai társaik, rokonaik számára. A feudalizmus leghathatósabb ideológiai támasza Magyarországon a katolikus egyház volt. A társadalmi elömenetelhez így szempont volt a fớr vallási hovatartozása. A felekezeti hovatartozás szerint jellemző volt az a területi megoszlás, hogy a történelmi Magyarország középső részén élő főnemesi családok általában római katolikusok, az erdélyiek többségében reformátusok voltak, a Felvidéken pedig inkább evangélikusok éltek. Ez vonatkozik egy család különböző országrészekben élő ágára is. A különböző felekezetü családok közötti vegyes házasságok sokszor komoly kompromisszumokra késztettek: a szokás szerint a fiúk az apjuk, a leányok az anyjuk vallását követték. A szigorúbb katolikus egyház reverzálist követelt, vagyis a protestáns társ belegyezését, hogy a gyermekek mindannyian katolikusok legyenek ${ }^{6}$

A reformált vallás és az e mentén kialakuló új egyházak, az újjászerveződő katolikus egyház intézményeinek létrehozása, fenntartása, az egyházi életben való aktív részvétel arra kötelezte a fourakat, hogy az európai átlagnál jobban tájékozódjanak vallási kérdésekben, egyházi ügyekben. A korabeli egyházi környezet pedig folyamatosan igényelte a közvetlen, személyes patronátust. Magyarországon olyan intézményes keretei is kialakultak a föurak egyházi életben való részvételének, mint a római katolikus zsinatokon való elnöklés vagy a Református Főkonzisztórium munkájában való napi feladatellátás. A förangú hölgyek esetében ebben a korszakban a civilizált élet fokmérőjeként a könyvolvasás jelent meg. Olvasmányaik között a napi vallás-

\footnotetext{
${ }^{4}$ http://magyar-irodalom.elte.hu/nevelestortenet/jegyzet.html\#jzt311 (Utolsó megtekintés: 2019. 07. 10.)

${ }^{5}$ Virág 2007. 49.

${ }^{6}$ Gudenus-Szentirmay 1989. 158-159.
} 


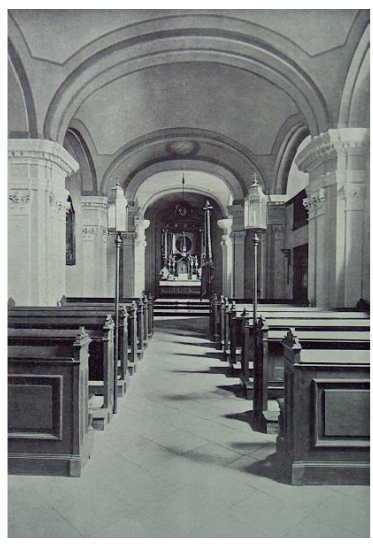

a)

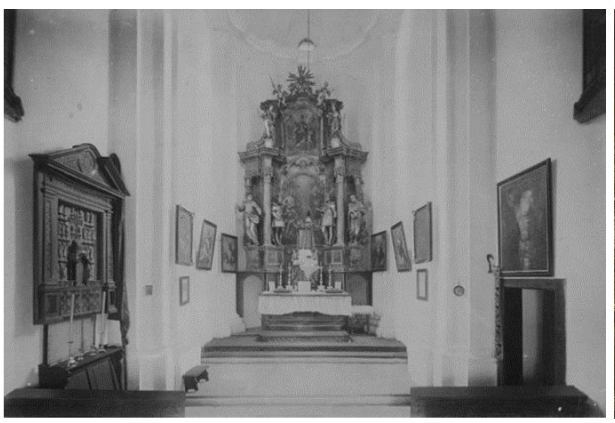

d)

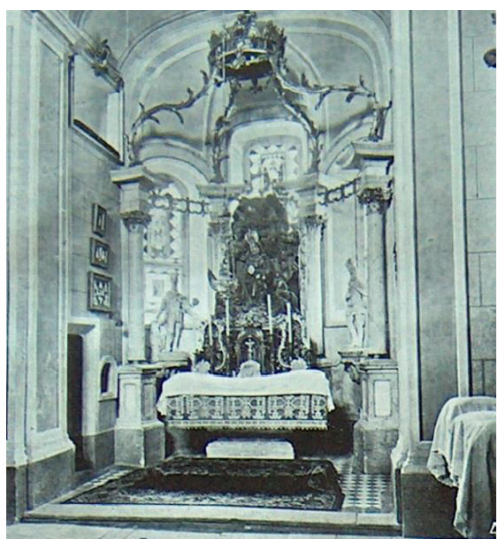

b)

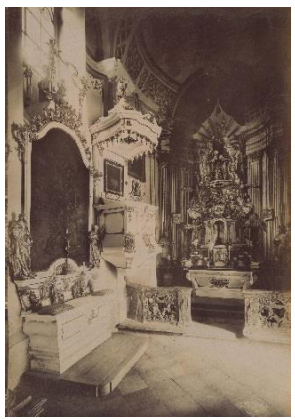

e)

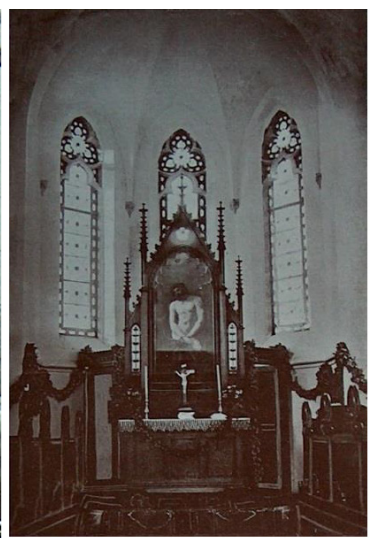

c)

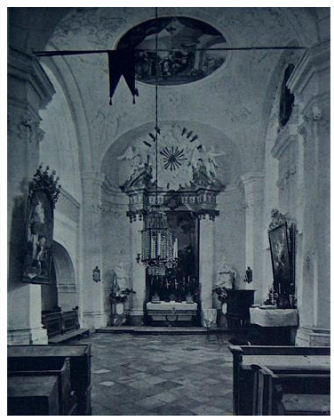

f)

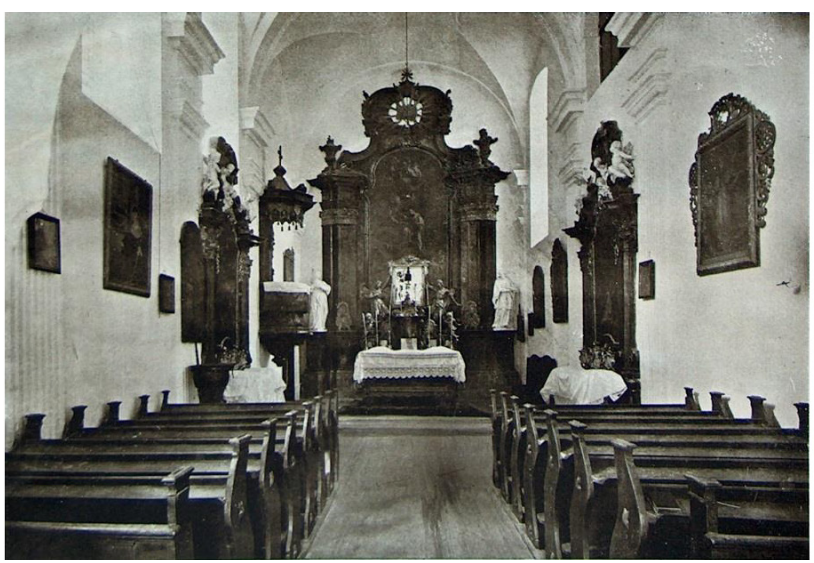

g)

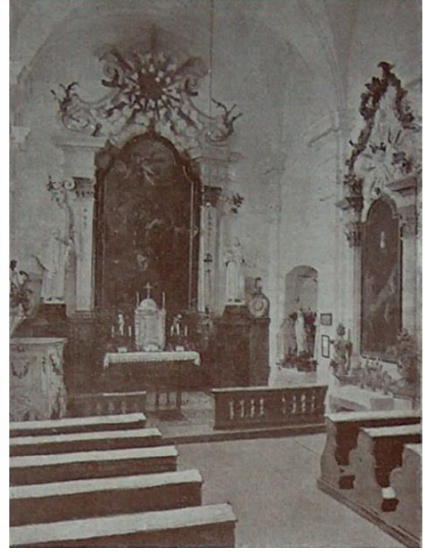

h)

\section{1. ábra}




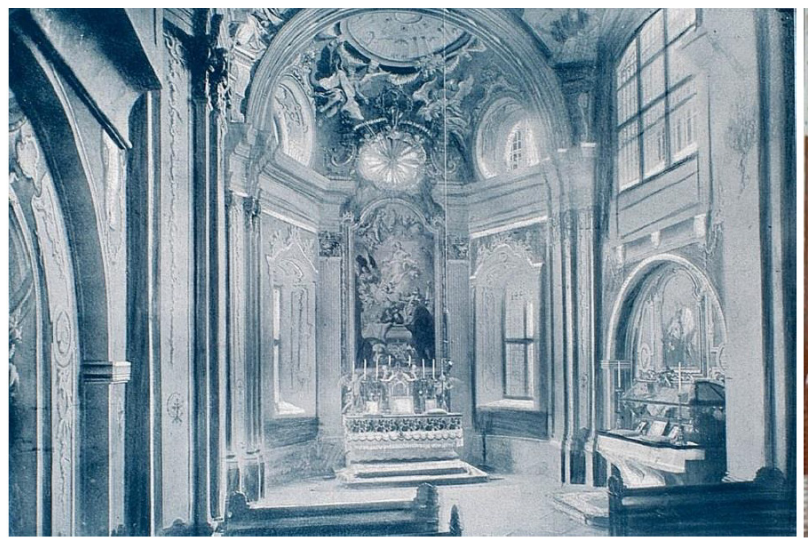

i)

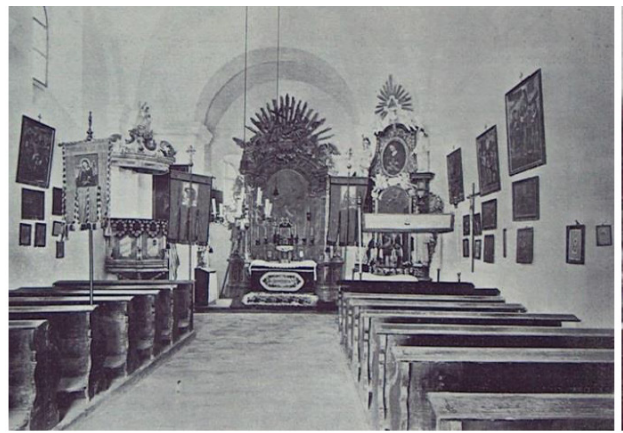

k)

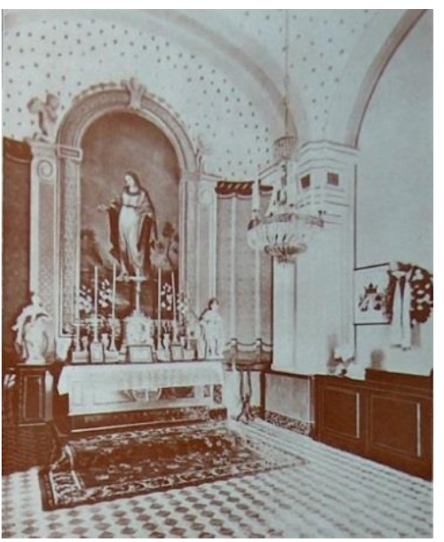

j)

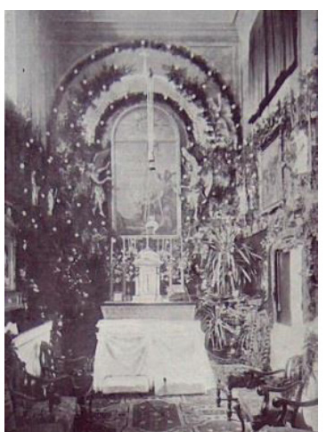

l)

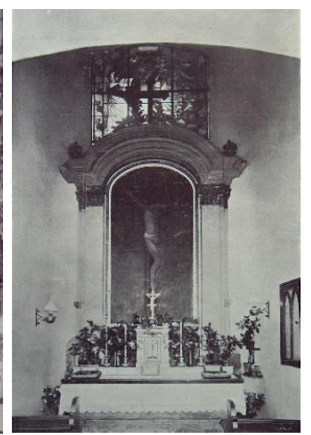

m)

1. ábra. A reprezentatív nyilvános és félig nyilvános házi kápolnák példái a 18-19. századból: a) Nagybodok; b) Galgóc; c) Brogyán; d) Muraszombat; e) Füles; f) Magyarbél; g) Kékkő;

h) Zsigmondháza; i) Szentantal; j) Petőfalu; $k$ ) Nagyzáblat; l) Sopronhorpács; $m$ ) Alsókorompa

gyakorlat - ájtatossági, kegyességi, a középkori misztika felélesztésével lebilincselö - könyvei első helyen szerepeltek, de emellett a házi patika fogásait leíró müveket, szakácskönyveket és természetesen szépirodalmi müveket is forgattak. ${ }^{7}$

A 18-19. század fordulóján a förangú hölgyek képzése szerény alapokon nyugodott. Általában müveltségüket a német vagy francia nyelvü írás, olvasás, a vallási és mitológiai alapismeretek, valamint szegényes földrajzi ismeretek alkották. Tanításuk szinte kizárólag a főként francia származású nevelőnők gondjaira volt bízva, akik magasabb szintủ nőnevelö intézetek híján maguk is csupán szerényebb ismereteikre hagyatkozhattak. Az elmélyültebb ismeretek iránti igény csak a 18. század végén jelent meg, amikor a förangú szülők már megengedték, hogy leánygyermekeik is

\footnotetext{
${ }^{7}$ Monok 2010. 6-8.
} 


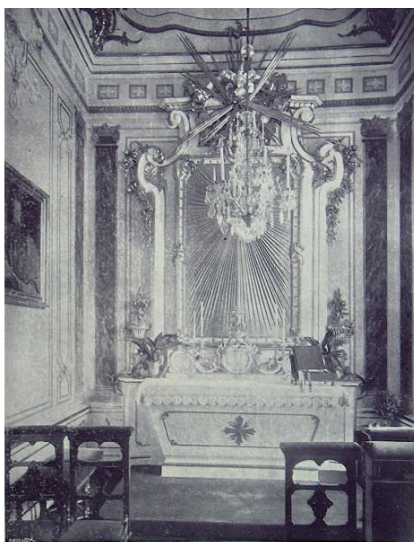

a)

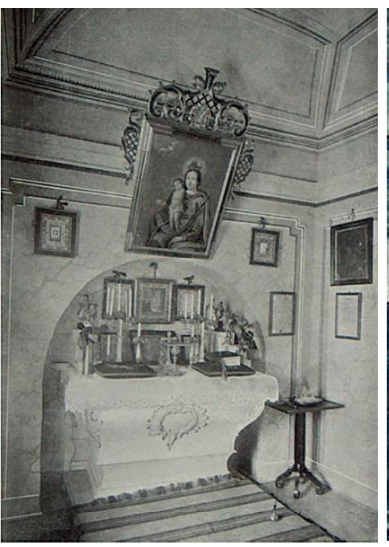

b)

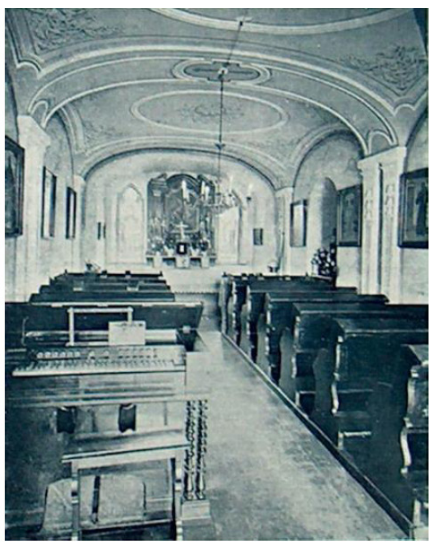

c)

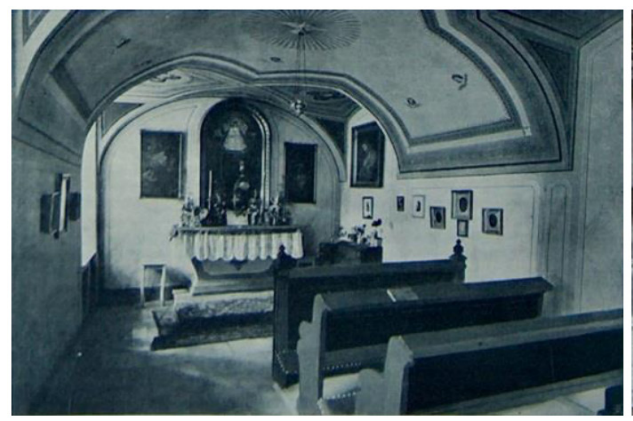

d)

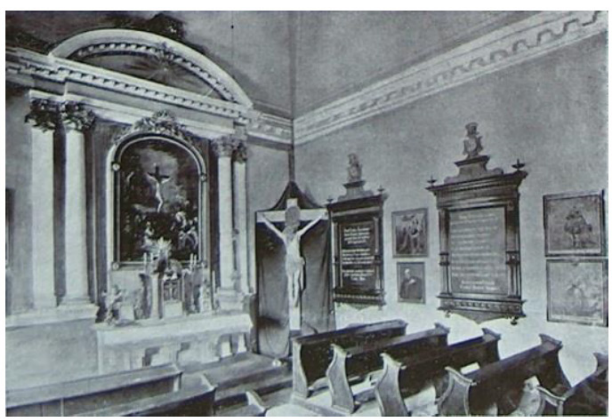

e)

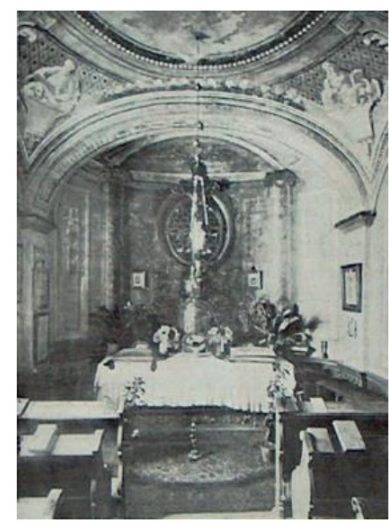

f)

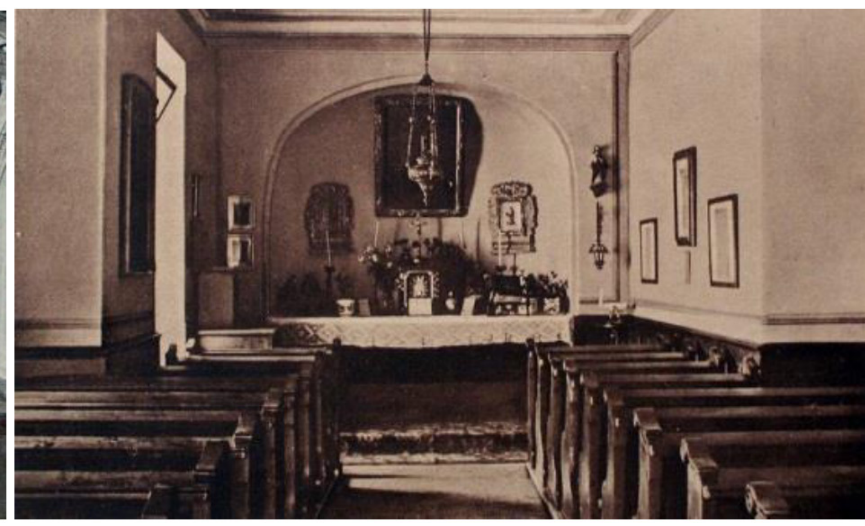

g)

2. ábra 


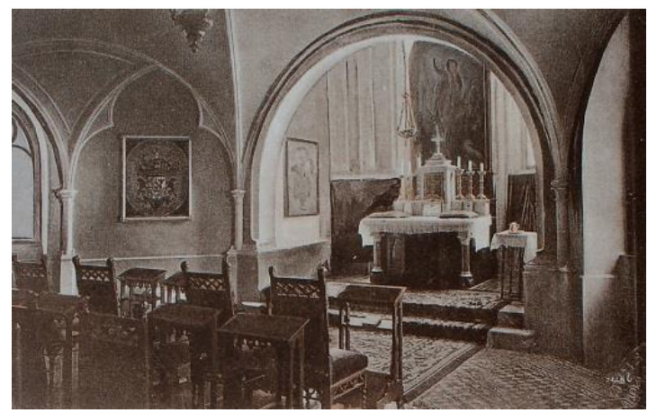

h)

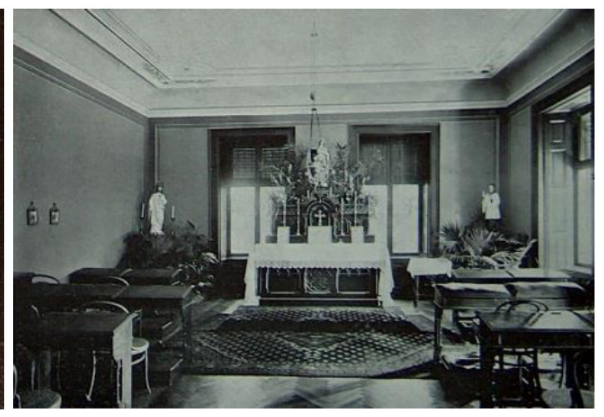

i)

2. ábra. A fớri magánkápolnák példái a 18-19. századból:

a) Féltorony; b) Osgyán; c) Köpcsény; $d$ ) Lajtaújfalu; e) Szepesmindszent; f) Csombárd; g) Parádfürdö; $h$ ) Nagykároly; i) Nógrádgárdony

részt vehessenek fivéreik tanítási óráin, vagy ritkább esetben külön házitanító foglalkozott tanításukkal. Az egyházi gimnáziumi képzés meghatározó részeként a hit- és vallástan a keresztény vallás alapigazságainak, a bibliai történeteknek és az evangéliumoknak az elsajátítását foglalta magába. A történelem is föként a hittannal volt kapcsolatos, valamint a napi rendhez a tanórákat követő közös vallásgyakorlás is hozzátartozott. A 18. század végén a jó nevelés céljai között második helyen szerepelt a ,jó keresztyén”. Az erkölcsi nevelés tekintetében a vallási előírások, az általános emberi értékek, valamint a társasági normák betartása alapvető volt. A korszak felfogása szerint jó keresztény akkor válhatott az ifjúból, ha „,a maga vallását jól megtanulja, és az abból vett princípiumokat mind az Isten, mind embertársai mind maga iránt való kötelességeire nézve szenteknek tartja"» (1-2.ábra).

\section{A HÁZIKÁPOLNÁK FUNKCIONÁLIS ÉS ÉPÍTÉSZETI SAJÁTOSSÁGAI}

A kápolna a középkori latin capella szóból ered, a mai köznyelvi értelemben alkalmilag használt kisebb templom, oltárral ellátott helyiség. ${ }^{9}$ A hatályos egyházjog szerint a kápolna lehet nyilvános, félig nyilvános vagy magánkápolna. A megkülönböztetés alapja az, hogy az adott hely milyen mértékben szolgált a hívő nép használatára. A nyilvános kápolna (oratorium publicum) fölszentelt istentiszteleti hely, ahová kívülállók is beléphettek. A félig nyilvános kápolna (oratorium semipublicum) mint istentiszteleti hely felszentelése nem volt kötelező, kívülállók általában nem látogatták. A magán-házikápolna (sacellum privatum) az egy vagy több személy ja-

\footnotetext{
${ }^{8}$ Virág 2007. 50, 66, 74, 86.

${ }^{9}$ Magyar Értelmező Szótár, Magyar Etimológiai Szótár. https:/www.arcanum.hu/hu/online-kiadvanyok/ Lexikonok-magyar-etimologiai-szotar-F14D3/k-F287B/kapolna-F2957/ (Utolsó megtekintés: 2019. 07. 11.)
} 


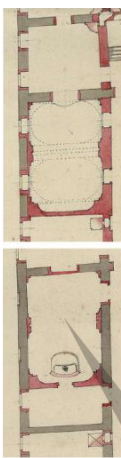

a)

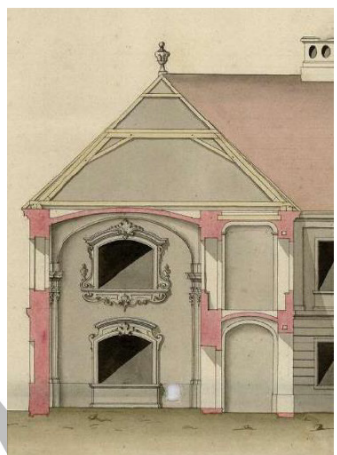

b)

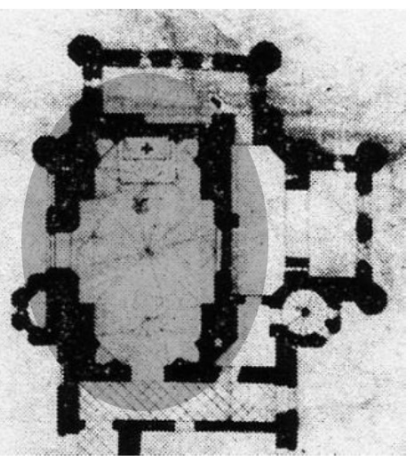

c)

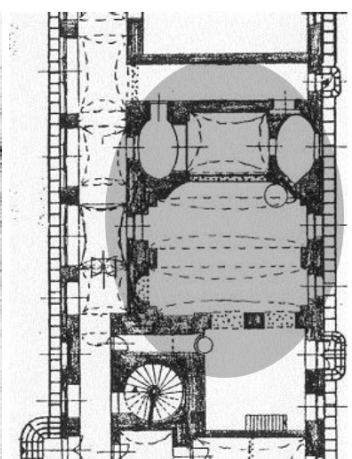

d)

3. ábra. A magánkápolnák ábrázolásának példái a 18-20. századból:

Vedrőd, a kastély átalakítási tervrészlete a 18. századból: a) Vedrőd, alaprajzok, b) metszet; c) Oroszvár, a kastély átalakításának részletrajza a 19. századból; d) Nagyláng, a kastély 1984. évi átalakításának rajzrészlete a kápolna ábrázolásával

vára, a helyi ordinárius engedélyével istentiszteletre rendelt hely volt. Az 1983 elötti egyházjog szerint a magánkápolna (oratorium privatum) a Szentszék engedélyével egyes családok vagy személyek istentiszteleti helye nem volt fölszentelhető, csendes mise kivételével liturgia nem volt végezhető benne. ${ }^{10} \mathrm{Az}$ oratórium imaház, magánkápolna, emeleti karzat jelentéssel ismert az építészetben, a szó a latin templum oratorium (imádkozásra való szentély) kifejezés második eleme nyomán, az orare, oratum (előad, kér, könyörög, imádkozik) igéből ered. ${ }^{11}$ A házikápolna, tehát a világi foúri lakóhelyekben az otthoni vallásgyakorlás legfontosabb színhelye, amely a 19. század közepéig jellemzően a fő́ri vallásosság szimbóluma volt. A házikápolnát elkészülte után ünnepélyes keretek között felszentelhették, a miséken kívül olyan jeles eseményekkor is használták, mint a keresztelők vagy az esküvők. Számos esetben a házikápolna látta el a személyzet és a település lakóinak lelki gondozását is. ${ }^{12}$

A házikápolnák történeti kialakítását a 18-19. századi berendezésleltárak részletes összeírásai, a korszakból fennmaradt Canonica Visitacio jegyzőkönyveinek leírásai, építészeti rajzok (tervek és felmérések), visszaemlékezések, leírások forrásai, 19-20. század eleji fényképfelvételek mutatják hitelesen. A házikápolnák legfontosabb - gyakran épített - eleme és berendezése az oltár (altare), vízszintes része a menza (mensa), az eucharisztikus áldozat asztala volt. Jellemzően a szilárd (a padlóval egybeépített, egy vagy két lépcsőfokra emelt) változata terjedt el a házikápolnákban is, amelyet a régi építészeti rajzokon mindig jelöltek (3. ábra). A menza lehetett hordozható, áthelyezhető bútor is, amely a 19. század második felében lett gyakoribb. A házikápolnákban az oltár kizárólag a fal elé került, felette a falat architektonikus

\footnotetext{
${ }^{10} \mathrm{http} / / /$ lexikon.katolikus.hu/K/K\%C3\%A1polna.html (Utolsó megtekintés: 2019. 07. 11.)

${ }^{11}$ Magyar Etimológiai Szótár. https://www.arcanum.hu/hu/online-kiadvanyok/Lexikonok-magyaretimologiai-szotar-F14D3/o-o-F33F0/oratorium-F3488/ (Utolsó megtekintés: 2019. 07. 11.)

${ }^{12}$ Óhidy 2007. 200-201.
} 


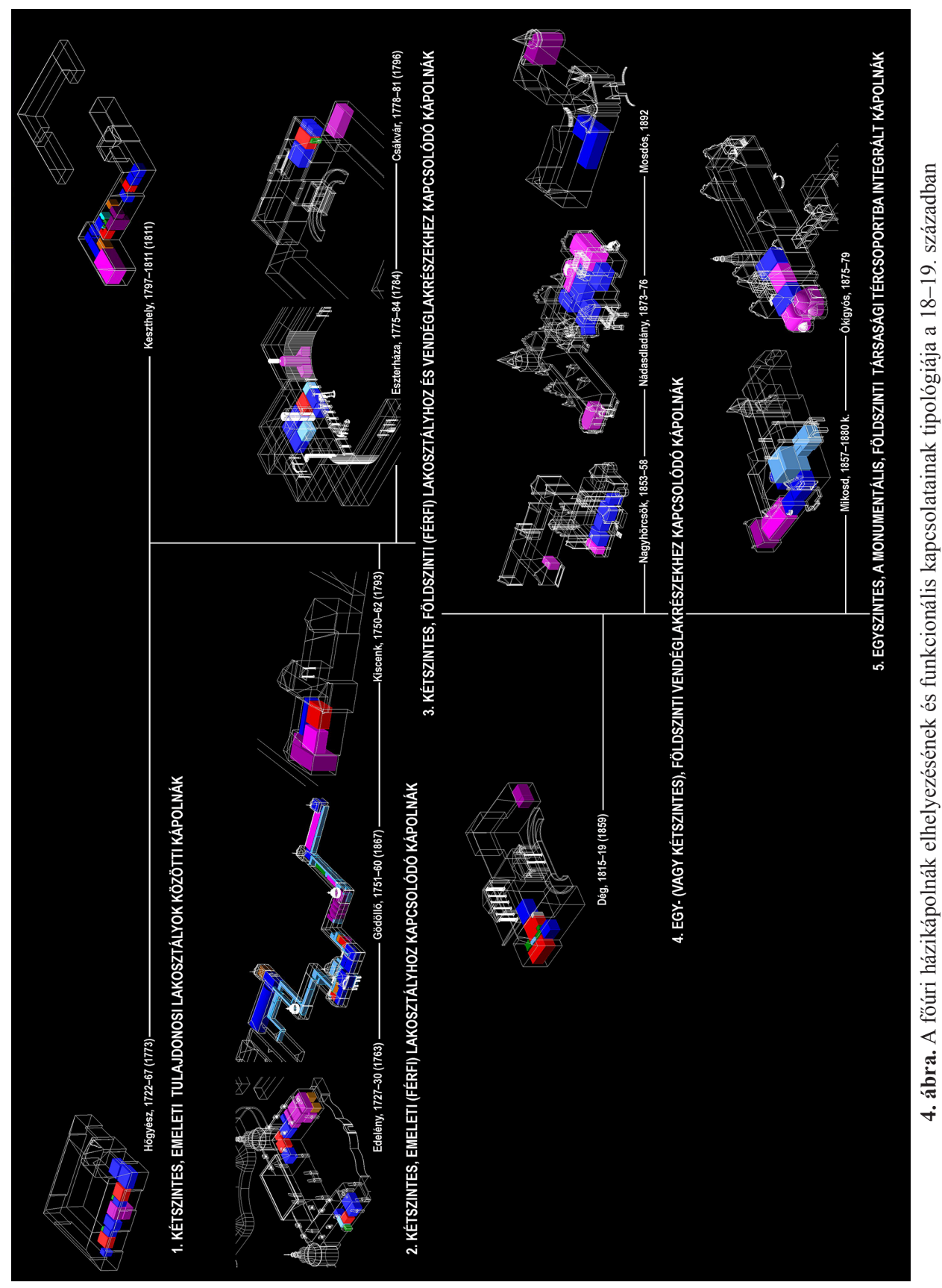


keretezésbe illesztett képzőművészeti elemekkel (a kápolna szentjét ábrázoló oltárkép, az oltárkereszt) díszítették. Az eucharisztia tiszteletéből megszülető és az oltárra épített tabernákulum - ami egyúttal a monstrancia foglalata is volt - a fóúri házikápolnákban is megjelent. Az oltár előtti térszakasz a szentély - a résztvevőknek háttal miséző pap mozgástere - volt, amely építészeti eszközökkel ritkán, illetve jellemzően csak a 18. századi nyilvános kápolnákban különült el a házikápolna terétől. A házikápolnák térkompozíciója a liturgia egyszerüsített változatára specializálódott, amelynek során a fóúri, valamint a köznépi együttes jelenlét funkcionálisan differenciált, tagolt téralakítást eredményezett.

A többszintes házikápolnák terének meghatározó épített eleme a karzat (empórium), a hívők megkülönböztetett csoportjának - a házikápolnák esetében a tulajdonosok és foúri vendégeik - imahelye volt. Az oratórium-karzat jellemző elhelyezése a 18. században az oltárral szemben, az udvari bejárat fölött vagy a szentély két oldalán volt. Előbbi esetben a tulajdonosi lakosztályból vagy a vendéglakrészeket feltáró folyosóról, előterekből volt megközelíthető, utóbbi esetben a karzatok falba rejtett lépcsőkröl, keskeny folyosókról voltak elérhetők. Az 1850 elötti évtizedben - az egy helyiségből álló, kisebb magánkápolnákban - a karzat emelvényszerü kialakítása, a szentély terétöl mellvéddel történő elválasztása és külön bejárata volt sajátos építészeti megoldás (4. ábra).

\section{A VALLÁSOSSÁG MONUMENTÁLIS REPREZENTÁCIÓJA A NYILVÁNOS HÁZIKÁPOLNÁKBAN}

A 17-18. századi katolikus főnemesség hazánkban sem nélkülözte az erőt, a biztonságot, a társadalmi rend isteni eredetének tudatát kifejező világnézetet. A főúri vallásosság ezért tele volt reprezentatív vonásokkal, a fönemesek rendületlen és határozott hittel vélték, hogy cselekedeteiket és terveiket Isten pártfogásával viszik végbe. A válságba jutott humanizmusnál és a demokratikus elemeket is magába foglaló protestantizmusnál sokkal alkalmasabb volt minderre a katolikus vallás. Az építtető föurak saját nagyságuk és meggyőződésük képét is viszont akarták látni az általuk finanszírozott épületekben, amely - a korabeli építészet jellemző vonásaként az építtető és az épület szoros szubjektív kapcsolatát jelentette. E hitbeli meggyőződés legalkalmasabb kifejeződése lakóhelyeik házikápolnájában tipikusan megvalósulhatott. ${ }^{13}$

A 18. században - örizve a késő középkori hagyományt - a reprezentatív nyilvános házikápolnák tere két vagy három szint magas csarnoktér volt, de - kisebb léptékben - ezt a térformát alkalmazták a magánkápolnák esetében is. A 18-19. században a házikápolnák funkcionális kapcsolata és diszpozíciója rendkívüli változatosságot mutatott. Jellemző, de nem kizárólagos volt a földszinti elhelyezés, az 1850 előtti emlékeknél az épületen belüli térkapcsolatot a föúri oratórium-karzat biztosí-

${ }^{13}$ Bővebben 1. Cs. Dobrovits 1983. 16-28; Mojzer 1971. 18. 
totta, amely jellemzően a férfi lakosztály felől - annak földszinti vagy emeleti elhelyezésétől függetlenül - volt megközelíthető. Ugyanakkor kivételes funkcionális kapcsolatra is volt példa, ahol a kápolna a nöi oldalon helyezkedett el, és volt példa a két tulajdonosi lakosztály közötti, vagy a vendéglakrészekhez kapcsolódó elhelyezésre is. Valamennyi változat sajátossága, hogy a házikápolna az épületkompozíció szempontjából nem hangsúlyos, nem kitüntetett, központi helyen - hanem pl. az épületszárny végén, épületsarkon - volt még akkor is, ha reprezentatív építészeti kialakítást, gazdag felszerelést kapott és nagy alapterületet foglalt el.

Zsámbékon gróf Zichy I. Péter (1674-1726) és első neje, homonnai Drugeth Klára a középkori eredetű udvarházat 1699-ben állította helyre, majd 1708-1725 között újjáépítve ${ }^{14}$ jelentősen ki is bővítették. A kastély házikápolnáját Xavéri Szent Ferenc tiszteletére szentelték fel 1719 után, amikortól a plébánia községi istentiszteletek céljára is használhatta. A korabeli állapot a kastélyról fennmaradt leírások és leltárak, ${ }^{15}$ valamint a későbbi, de még a jelentős átalakítások előtti időből származó, 1774 körüli alaprajzok (5.a ábra) elemzésével mutatható be.

A kastély északi szárnyában lévő kápolna udvari homlokzata előtt húzódó hosszú, egyenes karú lépcső (Eingangl) az emeleti előszobába (Eingang Zümer) vezetett. Ebből az egyik oldalon nagy (nappali) szoba (Zümer) nyílt, átjárással a kápolna oratórium-karzatára (Oratorium in die Kirchen). A földszinten a kápolna (Kirchen) egy elötéren keresztül volt megközelíthető, amelynek közvetlen külső bejárata az északi homlokzaton nyílt. Az előtérrel szemben az oltár nyugatra tájolva állt, amelynek jobb oldalán sekrestye, bal oldalán kis elötéren keresztül egy csigalépcső nyílt, utóbbi az oltár feletti emeleti oratórium-karzatra vezetett fel. A csigalépcső előtere az udvarról felvezető lépcső felől közvetlenül kívülről is megközelíthető volt.

Az edelényi kastélyt 1727-1728-ban báró L’ Huillier Ferenc János (1668-1728) császári kapitány építtette ismeretlen építész tervei alapján. Az 1763-1764. évi felmérésekből és inventáriumokból rajzolódik ki az akkor már gróf Esterházy István birtokában lévő kastély és park korabeli rendeltetésrendszere (5.b ábra). A kastély kápolnájában 1872 előtt a szendrői ferences rendi konvent szerzetesei teljesítettek szolgálatot. 1826-ig a kápolna a borsodsziráki egyházközséghez tartozott. Ez utóbbi időszakban Dessewffy Ferenc gróf áldozatkész patrónusi tevékenységéhez tartozott, hogy a miséken maga orgonált. ${ }^{16}$

A női lakosztály grófnői szobájából (Gräfin Zimer) nyílt a Szűz Mária tiszteletére felszentelt udvari kápolna (Hoff Cappeln) terébe nyúló karzat (Herschaffts oratorium), amelynek szimmetrikus párja (Gäst oratorium) a foúri vendégek imahelye volt. A kápolna földszintjén, a keletre tájolt oltárral szemben az udvarról közvetlen bejárat nyílt. A kápolna északi oldalán az oltár mellett a sekrestye (Sacristay), mellette, abból nyílóan a káplán szobája (Capplan Zimern) és kamrája helyezkedett el, előbbiből kijárattal az udvarról nyíló folyosó (Ein Gang) felé. A kápol-

${ }^{14}$ Gy. Balogh 2007. 26.

${ }^{15}$ A kastély átalakítás előtti állapotát az 1685. évi összeírás, az átalakítás utánit az 1727-ben készített részletes leírás és berendezési leltár mutatja. MNL-OL P 707. Zs. № 5. „Castellum Sambek”.

${ }^{16}$ Krász 2014. 134. 


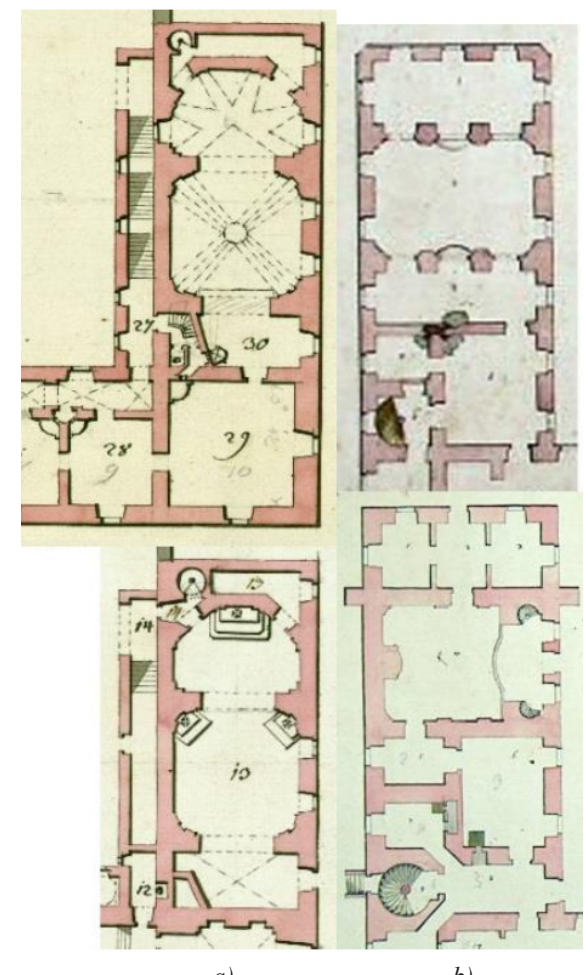

a)

b)

5. ábra. A nyilvános házikápolnák példái: a) Zsámbék; b) Edelény

na déli oldalán, a vendégek karzata alatt a tervrajz bejáratot jelöl (Gang in die Kirchen), amelynek udvari oldalán a templomi tárgyak raktára (Kirchen Sachen Conservatorium), ezzel szemben „Krisztus sírja” (Sepulchru Christi) kapott helyet. A karzatokra való feljutást két, falba rejtett csigalépcső biztosította.

Gödöllőn gróf Grassalkovich Antal (1694-1771) kastélyának második építési periódusában 1746-1749 között a korábbi háromszárnyú épületet ötszárnyúvá bővítette. Az udvari épületszárnyak végéhez két új oldalszárnyat kapcsoltak. A délihez istállót építettek, az északiban pedig a kor egyik legnagyobb házikápolnáját alakították ki. A kápolna tervét nagy valószínüséggel - ahogyan a megelőző építési periódust is - a salzburgi születésủ Mayerhoffer András (1690-1771) készítette. A templom alapkövét 1746. április 22-én gróf Althann Mihály Károly (1702-1756) bari érsek, majd váci püspök rakta le ünnepélyes keretek között, és Nepomuki Szent János tiszteletére 1749. május 16-án ő végezte a kápolna felszentelését is. A kápolna az Isaszegi Római Katolikus Plébánia filiáléjaként müködött, az isaszegi plébános volt a gödöllői katolikus kápolna irányítója, helyben pedig egy káplán látta el a lelkipásztori feladatokat. A kápolna 1769-től volt önálló plébánia. 1811-ig a besnyői kapucinusok 
teljesítettek itt szolgálatot, közülük kerültek ki a káplánok is. 1837-1838-ban a kápolnát renoválták, a régivel egyező, új boltozatokat építettek Hild József tervei szerint, amelyeket architektonikus festéssel dekoráltak. ${ }^{17}$

Mária Terézia királynő 1751-es gödöllői látogatásakor a kastélykápolnában (6. ábra) is járt: „Másnap reggel [augusztus 11.] a felségek kiséretükkel megtekintették a kastélyt... 10 órakor a fekete márvánnyal és arannyal dúsan díszitett kápolnába mentek, ahol szentmisét hallgattak." Ennek helye a kápolna déli oldalán kialakított emeleti oratórium-karzat volt, amelyet - az 1868. évi inventárium ${ }^{18}$ alapján - az északi szárny végében kialakított emeleti vendéglakosztály nappali szobájából (Zimmer for dem Oratorium) lehetett megközelíteni. Az oratórium nyugati sarkában íves falfülke kapott helyet imazsámollyal, keleti oldalán kis csigalépcső vezetett le a földszinti kandallós szobába (Kamin $N^{\circ} 8$.). A kápolna külső bejárata az északkeleti homlokzaton nyílt. Az oltár északnyugatra tájolt, két oldalán egy-egy falfolyosó kis csigalépcsőben végződött, amelyek egy-egy karzaton keresztül a mindkét oldalon, a szimmetrikusan elhelyezett szószék megközelítését tették lehetővé. A sekrestye a szentély délnyugati oldalán kapott helyet.

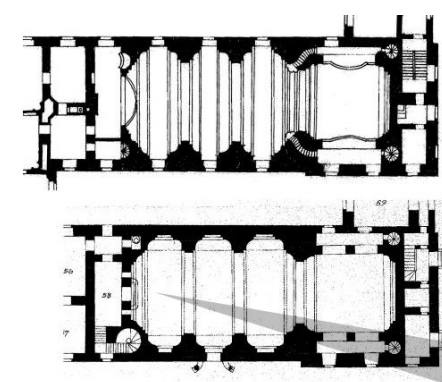

a)

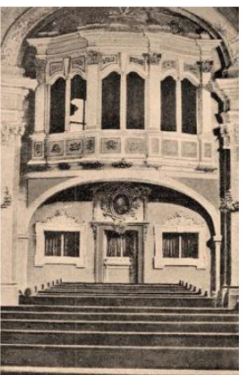

b)

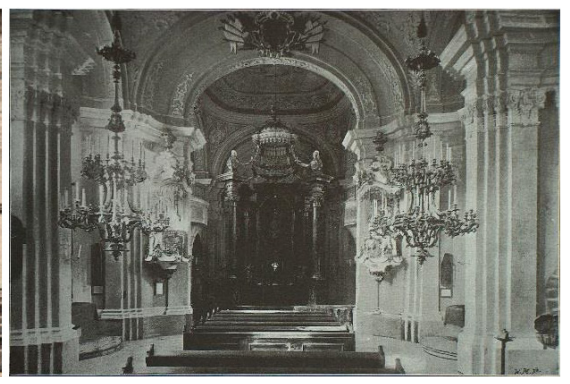

c)

6. ábra. Gödöllő: a kastélykápolna $a$ ) alaprajzai, $b$ ) urasági oratórium-karzat, $c$ ) belső látképe

A budavári királyi palota bővítése elsősorban Jean Nicolas Jadot (1710-1761) és Oraschek Ignác (†1767) tervezői és kivitelezői munkásságához kötődik. 1749-1758 között - kisebb megszakításokkal - Nicolaus Paccassi (1716-1790) müködött az építkezésen. Franz Anton Hillebrandt (1719-1797) 1765-1769-ben és 1770-ben ${ }^{19}$ készített terveket, és az elkészült palota 1791-ben Sándor Lipót királyi helytartó (1790-1795) székhelye lett. ${ }^{20}$ Az 1767-ben befejezett királyi palotában emelt udvari kápolnát, a mélyen vallásos Mária Terézia királynő azzal a kikötéssel adta a Szent Zsigmond prépostság kanonokainak, hogy állandó lakhelyüket Pozsonyból Budára tegyék át azzal a céllal, hogy a plébánosi feladatokat ellássák. Az udvari kápolna neve 1900-ig Szent Zsigmond, 1900-tól Szent István magyar királyról nevezett plébánia, majd Magyar Királyi és Udvari Vár-Plébániatemplom, Vártemplom, Udvari Templom, Várkápolna, Királyi Kápolna stb. volt²1 (7.a-d ábra).

\footnotetext{
${ }^{17}$ Varga 2003. 39.

${ }^{18}$ MNL-OL K271-6. cs. 16538. 1868.

${ }^{19}$ Kelényi 1976. 39-41.

${ }^{20}$ Markó 2000. 242.

${ }^{21}$ Voit 1955; Mojzer 1971.
} 
Az udvari kápolna a palota délnyugati szárnyában, a királynői lakosztályhoz felvezető lépcső melletti udvar déli oldalán kapott helyet. Az oratórium-karzatra a királylépcső udvari oldalán húzódó folyosó vezetett. A kápolna főbejárata az Oroszlános udvarról nyílt, de megközelíthető volt a királylépcső előterét adó kocsiáthajtó csarnokából is. Az oltárt északnyugatra tájolták, mögötte a szentélyt körülfogó folyosó húzódott, amely felett az első és második emeleten karzatok nyíltak szintenkénti megközelítési lehetőséggel. A sekrestye a szentély északkeleti oldalára került a földszinten.

A kápolnához kripta is készült, amelynek bejárata csak a királyi palotából volt, bár eredetileg a kórus alatti részről induló keskeny lépcsővel tervezték a lejáratot. A kriptába a palotából a kápolna mellett a belső udvaron át vagy kívülről az oroszlános udvarról ugyancsak a belső udvaron át lehetett bejutni.

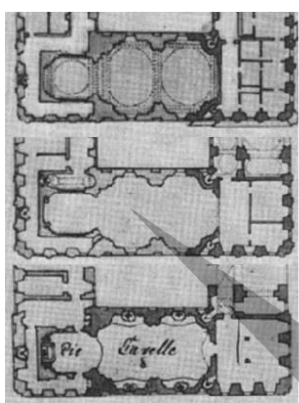

a)

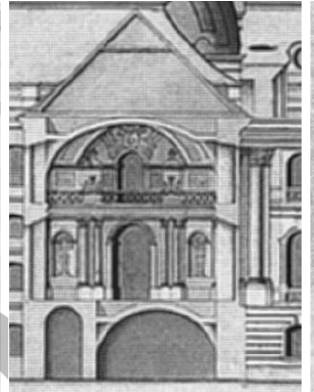

b)

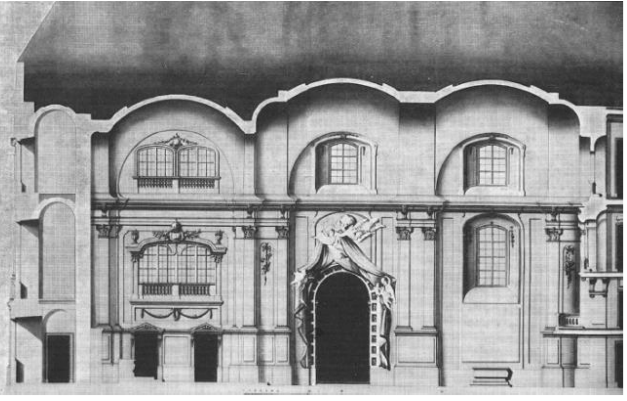

c)

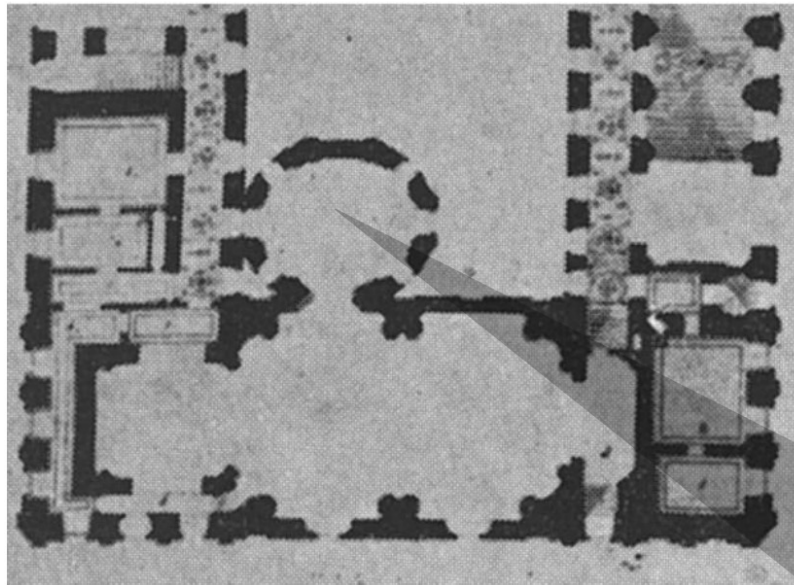

d)

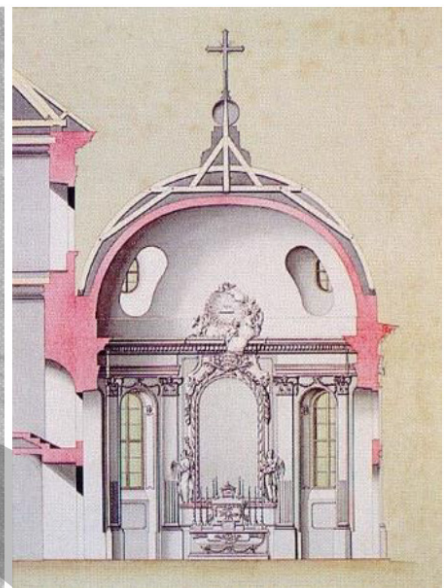

e)

7. ábra. A budai királyi palota kápolnái: Zsigmond-kápolna: a) alaprajzi tervezetek, b) keresztmetszet, c) hosszmetszet, d) megvalósult alaprajz; e) Szent Jobb-kápolna metszete 


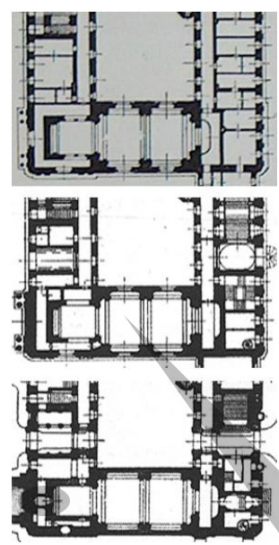

a)

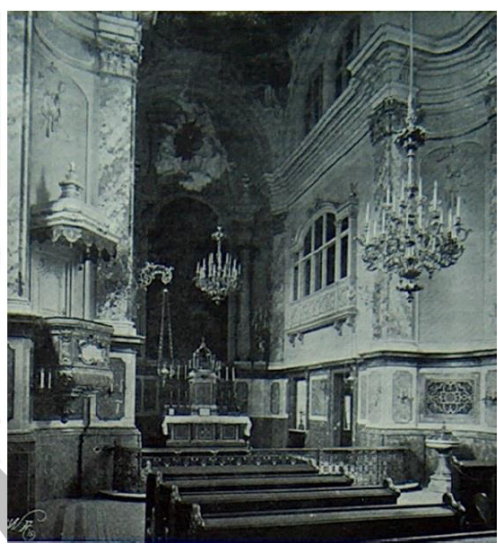

b)

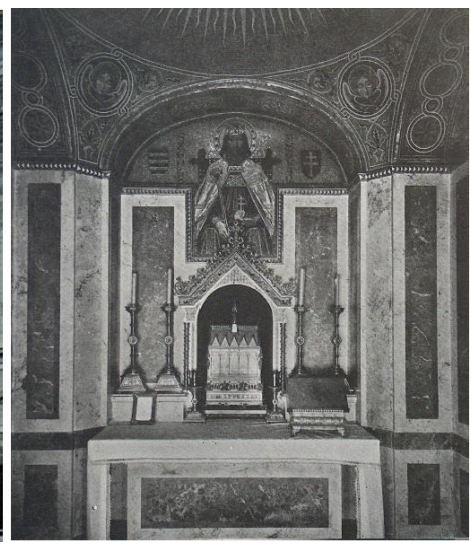

c)

8. ábra. A budai királyi palota kápolnái: Zsigmond-kápolna:

a) alaprajzok, b) belső kép az oltárral; c) az új Szent Jobb-kápolna oltára

Mária Terézia királynő 1771-ben Ragusából (ma Dubrovnik, Horvátország) viszszahozatta Budára államalapító Szent István király kézfejereklyéjét. Ennek állandó őrzésére egy kápolnát építtetett a Szent Zsigmond-kápolna oldalbővítményeként (7.e ábra). A terveket Franz Anton Hillebrandt készítette. Bár Szent István ereklyéjét már 1776-ben elhelyezték az új kápolnában, de az csak 1778-ban készült el teljesen.

A budavári királyi palotát az 1849-es szabadságharc pusztítása után - a kiégett Szent Zsigmond-kápolnával együtt - 1856-ban helyreállították ${ }^{22}$ (8.a-b ábra). I. Ferenc József magyar király 1882-ben határozta el a budai királyi rezidencia átépítését, amelyre Ybl Miklós (1814-1891) építész kapott megbízást 1882-től. Ybl 1891ben bekövetkezett halálával Hauszmann Alajos (1847-1926) vette át a tervezést, és irányításával 1891-1905 között befejeződött a várpalota korszerü királyi rezidenciává való kiépítése. ${ }^{23}$

A Szent Jobb-kápolnát - a belső udvar átrendezése és az újonnan nyitott északi kocsiáthajtó miatt - lebontották, a Szent Jobb örzésére pedig Hauszmann Alajos elfalaztatta a Szent Zsigmond-kápolna szentélye mögötti középső folyosó egy részét, és itt, a szentélyből a kápolna hossztengelyében ajtót nyitva alakíttatta ki a Szent Jobb-kápolna új terét (8.c ábra).

A Franz Anton Pilgram (1699-1761) 1750 körüli tervének tulajdonított, ún. vízi kastély földszinti és emeleti alaprajza (9.a ábra) fényképreprodukciókon maradt fenn.

\footnotetext{
${ }^{22}$ Voit 1955.

${ }^{23}$ Hauszmann 1911.
} 


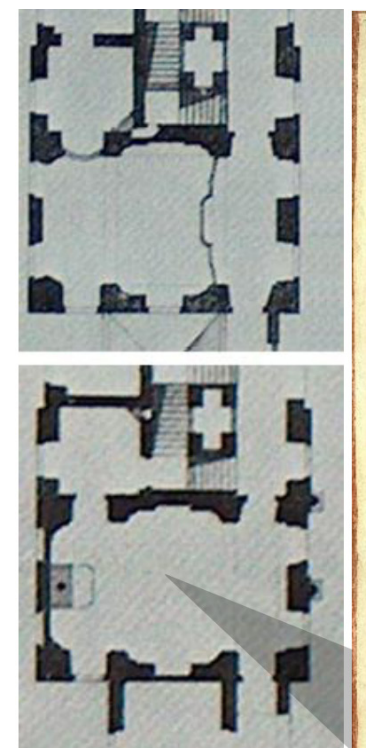

a)

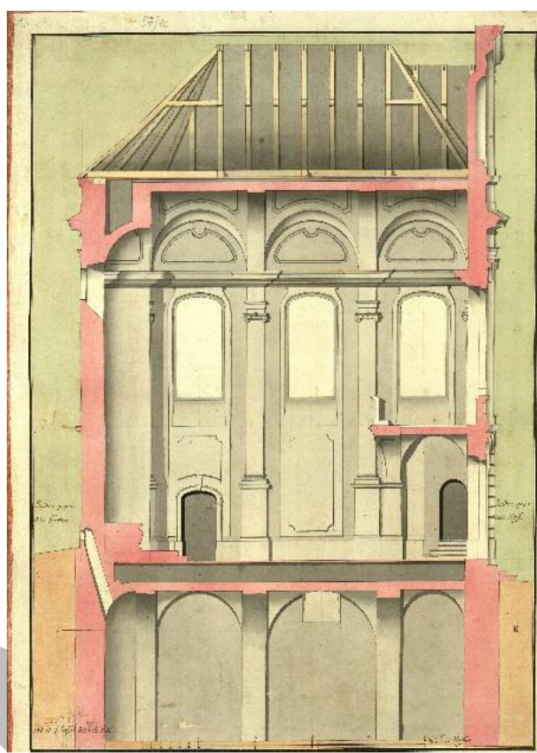

b)

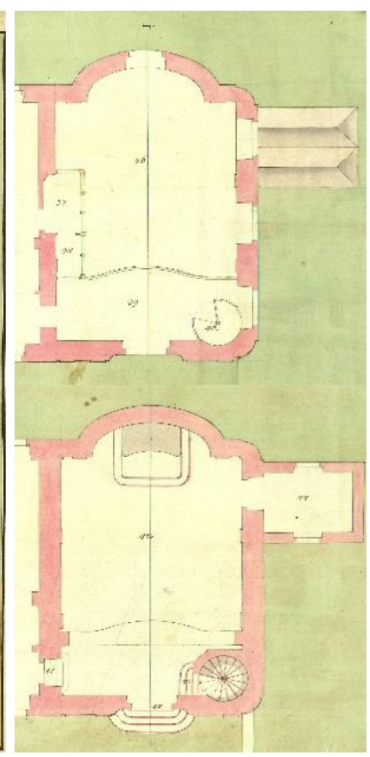

c)

9. ábra. A nyilvános házikápolnák példái: a) az ún. vízi kastély kápolnájának alaprajzai; Gyula, a tervezett kastély kápolnájának $b$ ) metszete, $c$ ) alaprajzai

A rajzok a föépület egyik oldalszárnyának végén kétszintes házikápolnát ábrázolnak, amelynek földszinti bejárata a fogadóudvarról nyílik, felette az emeleti oratórium-karzat az udvari homlokzat mögött futó oldalfolyosóról közelíthető meg. Az oltártól jobbra egy kisebb és különálló oratórium-karzat látható, amely az egyik emeleti lakosztállyal áll közvetlen kapcsolatban, illetve az egyik lakosztályból közelíthető meg. Alatta a földszinten a sekrestye kapott helyet, amely a kápolna mellett elhelyezkedő melléklépcsőházból közelíthető meg.

Harruckern Ferenc (1696-1775) báró gyulai régi kastélyán a 18. század második harmadában egy nagyszabású kiépítést tervezett, melyhez egy Franz Anton Hillebrandt (1719-1797) által 1760-1762-ben készített - meg nem valósult - tervsorozat ismert (9.b-c ábra).

A terv szerint a kastély északnyugati oldalrizalitjához külön épülettömeget alkotó házikápolna kapcsolódott volna. A kápolna északnyugati oldalán L alakú emeleti oratórium-karzat látható, amely az uralkodói vendéghálószobából és a mögötte lévő második kabinetből lett volna megközelíthető. A karzat északi sarkában csigalépcső vezetett a földszintre. Az oltár délnyugatra tájolt, megjelenését íves falfülke (apszis) hangsúlyozta. A tervrajz szerint az oltárral szemben nyílt volna a fogadóudvarról történő közvetlen, külső megközelítést lehetővé tevő bejárati ajtó. A kápolna északi sarkában az épülethez kapcsolt sekrestyét lehetett volna megközelíteni. 


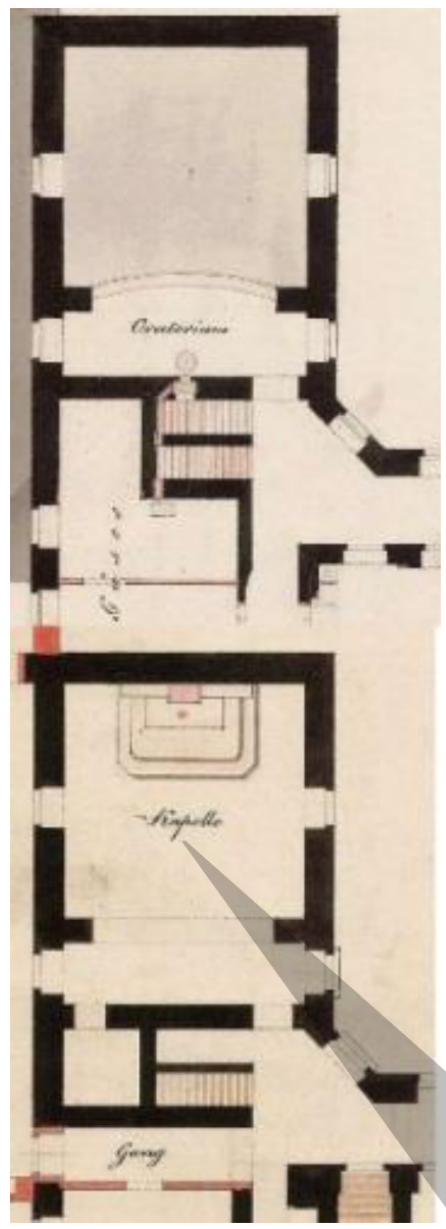

a)
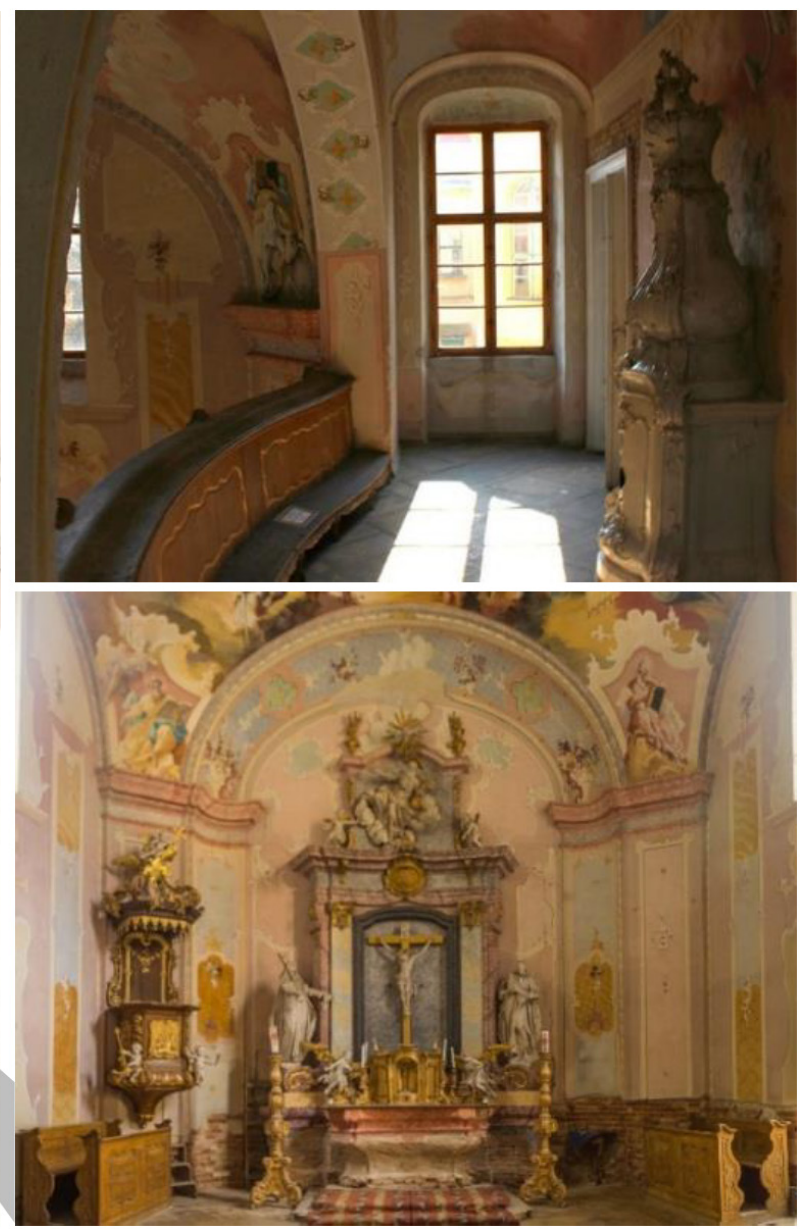

b))

10. ábra. Monok: a kastélykápolna a) alaprajzai, b) belső képei (oratórium-karzat és az oltár)

Gróf Andrássy György (*1704) az 1750-es években egy nagyobb és új kastély építéséről határozott Monokon. A kastélyt a kor igényeinek megfelelően 1760 és 1780 között emelettel és szárnyépületekkel bővítették fia, Andrássy István (17311812) megbízásából. 1770-1771 között készült a kastély délkeleti szárnyának kápolnája, ahol Szent Orbán vértanú ereklyéit őrizték. A kastély 1840 körüli állapota Ybl Miklós átalakítási tervsorozatáról (10.a ábra) ismert. 1881 után a kastélyt az Andrássy család már nem használta, ezért azt István unokája, gróf Andrássy Dénes (18351913) az Országos Gyermekvédő Ligának ajándékozta. 


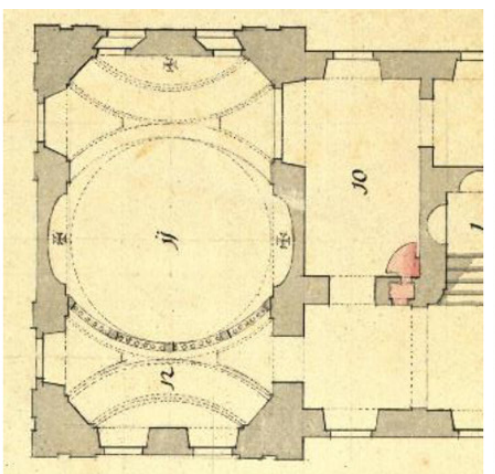

a)

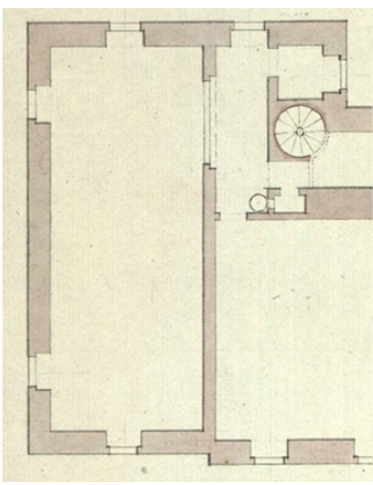

b)

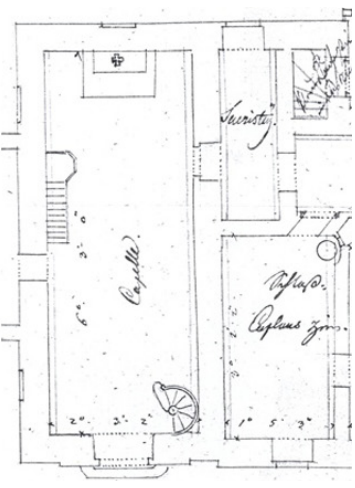

c)

11. ábra. Kiscenk: $a$ )-c) a kastély kápolnájának alaprajzi változatai

A kétszintes kápolna oratórium-karzata a vendégszobák előtti folyosóról nyílik, a bejáratnál kisebb melléklépcsővel. A karzat alatt kis előtér húzódik, amelynek földszinti bejárata az emeletivel azonos pozíciójú, ugyanakkor az udvarról egy közvetlen bejárat is idevezet. A karzattal szemben lévő fal elött álló oltár délkeletre tájolt. A sekrestye kis helyisége - szokatlanul - a karzat alatti elötérből nyílik.

Az 1741-1762 között, gróf Széchényi Antal (1714-1767) megbízásából épült kiscenki (ma Nagycenk) kastélynak Franz Anton Pilgram (1699-1761) építész 1750 körülre datált tervén már szerepelt házikápolna ${ }^{24}$ (11.a ábra). A mai kastély eredeti tervrajzait ${ }^{25}$ (11.b ábra) nem publikálták ugyan, de a kastély 1793. évi inventáriuma ismert. A kastélykápolna végső, 1945-ig fennálló formáját 1799-1800 között érhette el, amikor gróf Széchényi Ferenc (1754-1820) átalakíttatta és kibővíttette a kastélyt. A Szent Kereszt tiszteletére felszentelt kápolna különlegességét az adta, hogy VI. Pius pápa (1775-1799) búcsút engedélyezett számára.

A két épülettraktust átfogó, kétszintes kápolna a kastély keleti oldalának szélére került. A kápolna nyugati oldalán található emeleti könyvtárszobából nyílt az oratórium-karzat, amely az átalakítás után a kápolna északi oldalát foglalta el, szemben a délre tájolt oltárral. Az 1791. évi tervrajzon a karzat (Oratorium) a kápolna déli részén szerepel egy kis gyóntatófülkével (Gyontato Rekeszt). A későbbi karzat alatt a kápolna földszintjén az előudvarra vezető ajtó nyílt, a kápolna mellett, a nyugati oldalon lévő helyiség (Tisztelendő Pater Ur-Szobája) a káplán szobája volt.

${ }^{24}$ A terv nem valósult meg, de koncepciója alapját képezte az egyszerübb, elkészült épület tervének. Ennek tervezőjét nem ismerjük. Bővebben 1. Krámer 1973. 483.

${ }^{25}$ Hefele Menyhért (1716-1794) építész 1791. évi (meg nem valósult) átalakítási tervein azonban a 18. századi épület meglehetős bizonyossággal értelmezhető. Közli: Voit 1964. 256. 243. kép. 


\section{A 18-19. SZÁZADI KÉTSZINTES MAGÁNKÁPOLNÁK PÉLDÁI}

A hédervári udvarházat 1755-ben Viczay I. Mihály (1727-1781), valamint fia, II. Mihály (1757-1831) jelentősen átalakíttatta, és ekkor épült az új nyugati szárny végébe a két szintet átfogó, díszesen kifestett házikápolna is (12.a-b ábra).

A kápolna csak az előtte elhelyezkedő, belső folyosóról feltáruló előtérből volt megközelíthető a földszinten és az emeleten is egyaránt. A két szintet a kápolna mellett helyet kapó melléklépcső kötötte össze. A kápolna északkeletre tájolt oltárával szemben nyílt a bejárat, tőle balra - a saroktorony földszintjén - a sekrestye kapott helyet. A földszinten és az emeleten a kápolna mindkét oldalán egy-egy oratóriumhelyiség húzódott, amely az emeleten a lakószobákkal állt összeköttetésben.

A gróf Zichy Miklós (1710-1758) és neje, gróf Berényi Erzsébet (†1766 u.) 1746-1757 között, Jäger János Henrik (1708-1783) tervei szerint kiépített óbudai kastélyának 1774. évi tervrajzai fennmaradtak (12.c ábra).

A kastély északi oldalán egy kis keresztfolyosó (Ein Gangel und Thür in das Oratorium) tárta fel dél felől a kétszintes házikápolna emeleti oratórium-karzatát és közelében a földszintre vezető melléklépcsőt. A földszinti folyosóra a keleti homlokzaton ajtó nyílt, közelében a kápolna (Cappeln) bejáratával. Az oltár a karzattal szemközti, nyugati fal elött állt. Sekrestye nem tartozott a kápolnához.

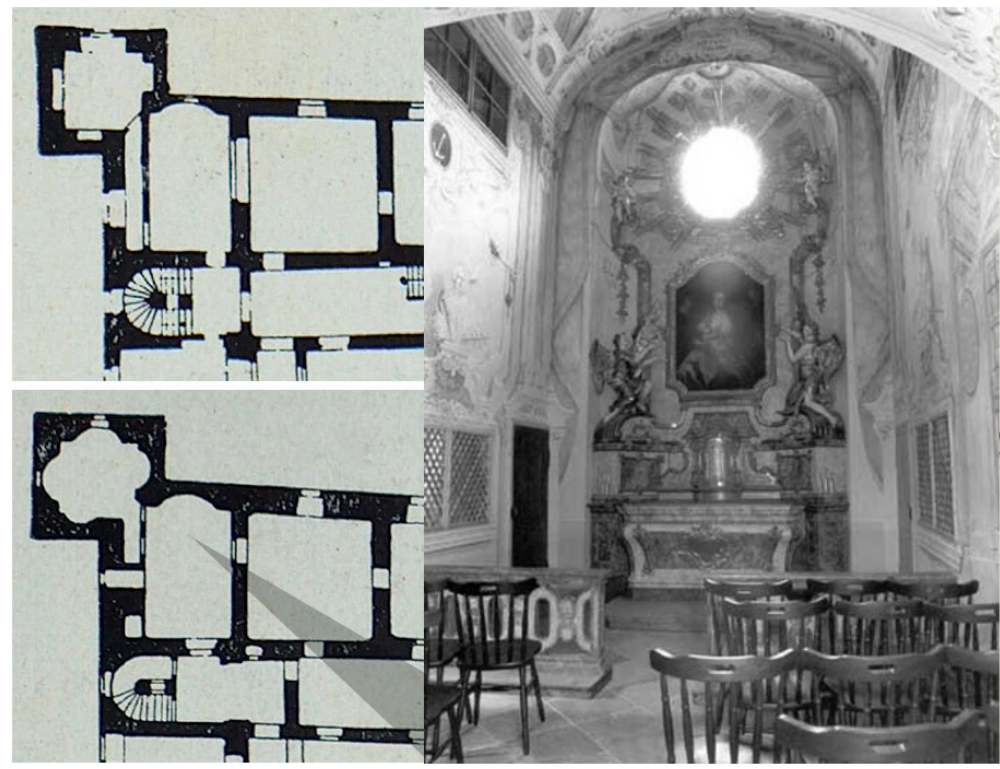

a)

b)

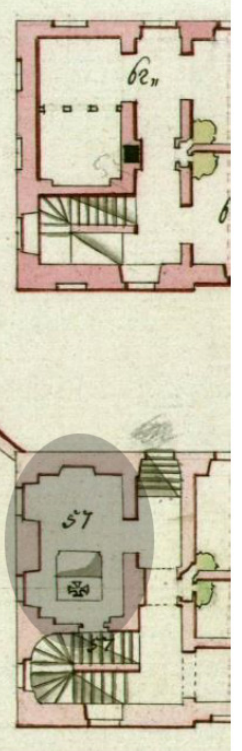

c)

12. ábra. A magánkápolnák példái: Hédervár: a) a kápolna alaprajzai, b) belső képe; c) Óbuda 


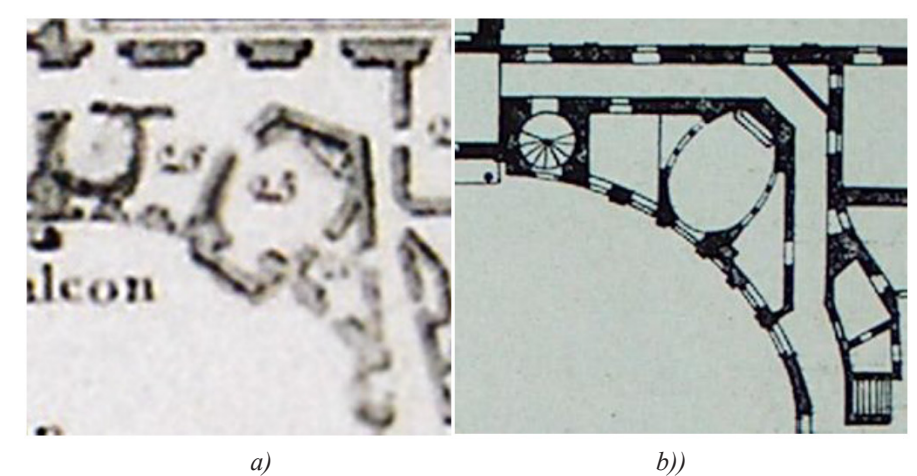

13. ábra. Eszterháza: a)-b) a kápolna alaprajzai

Herceg Esterházy Miklós (1714-1790) korábbi előzményeket felhasználó eszterházai kastélyának Hefele Menyhért (1716-1794) tervei alapján elkezdett, de Jakoby Miklós (1733-1784) tervei szerint befejezett, 1763-1769 közötti átalakítása ${ }^{26}$ során alakították ki a páduai Szent Antal tiszteletére felszentelt magánkápolnát (13. ábra).

A családi használatú, elliptikus alaprajzi formát mutató házikápolna (Kapelle) mindkét oldalán - mindhárom épületszinten - egy-egy oratórium-karzat (Oratorien) kapott helyet, amelyek a kápolna mögötti folyosóról voltak megközelíthetők. A földszinten a kápolna e folyosóval a hercegi lakosztályhoz kapcsolódott, az első emeleten a hasonló kialakítású folyosó az ebédlőterem (és elötere), valamint a vendéglakrészek között, a második emeleten a hercegi másodlakosztály előterei és a személyzeti szobák között biztosított összeköttetést. A kápolna földszintjén a délre tájolt főoltárral szemben közvetlen bejárás nyílt a fogadóudvarról.

Gróf Antoine Ignace Mercy d’ Argenteau (1692-1767) hőgyészi kastélyának, melyet a szakirodalom Franz Anton Pilgram (1699-1761) építésznek tulajdonít, ${ }^{27}$ két emeleti tulajdonosi lakosztálya az épület 1773 . évi leírása alapján ${ }^{28}$ és a közelmúltban végzett régészeti feltárások eredményeivel összevetve jórészt megismerhető.

A megkülönböztetés nélküli helyiségek (Cubicula) rendeltetése kapcsolódásukból sejthető: a belső, folyosóról közvetlenül megközelíthető, nagyméretü lakószobák lehettek a hálók, melyből kabinetek nyíltak. A leírásból ugyan nem derül ki, de valószínü, hogy a déli volt a férfi, nyugati párja a női lakosztály, a két lakosztályt pedig a kétszintes kápolna emeleti karzata - oratóriuma - kapcsolta össze.

Az 1784-1788 közötti átalakítás után az új kápolna (14.a ábra) a kastély északi sarokrizalitjába került, szintén kétszintes kialakítással. A kápolna délkeleti oldalán az emeleti folyosó északi részének lefalazásával alakították ki az oratórium-karzatot, alatta - hasonló módszerrel a kápolna föbejáratát, illetve kis előterét.

\footnotetext{
${ }^{26}$ Dávid 2000; Dávid 2002.

27 Voit 1982.

${ }^{28}$ Simon-Keresztessy 2002.
} 


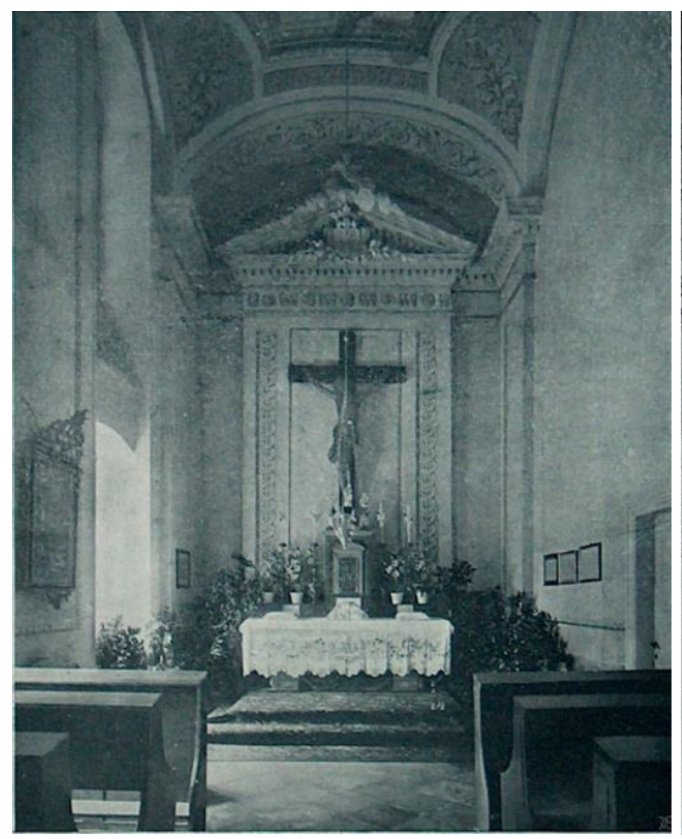

a)

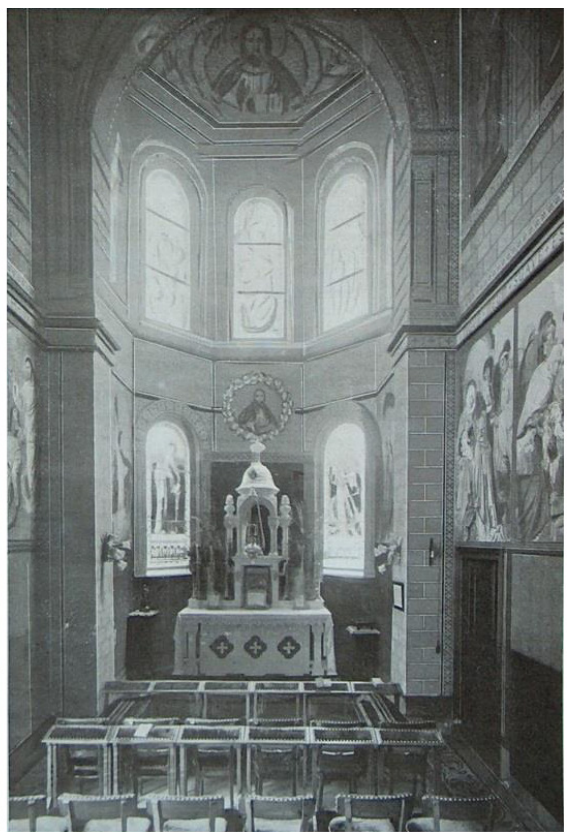

b)

14. ábra. A magánkápolnák példái: a) Hőgyész; b) Mosdós

Pallavicini György (1881-1946) örgróf eddig ismeretlen tervezővel, 1892-ben építtetett kastélyt Mosdóson. ${ }^{29}$

Az L alakú, kéttraktusos, középfolyosós kastélyépület északi szárnyának végén alakították ki a két szint belmagasságú házikápolnát (14.b ábra). A kápolna bejárata a folyosóról nyílt, vele szemben, a keletre tájolt oltár a homlokzat síkja elé lépő, poligonális záródású apszisban állt, amely az épületkülsőn toronyként jelent meg.

\section{A 18-19. SZÁZADI FÉLIG NYILVÁNOS ÉS LAKOSZTÁLYBAN ELHELYEZKEDÖ MAGÁNKÁPOLNÁK PÉLDÁI}

A nagyvonalú, attraktív kialakítású nyilvános házikápolnák mellett a kisebb, helyiségsorba illeszkedő, lakosztályokon belülre pozicionált, egyetlen helyiségből - esetleg elötérből és oratóriumhelyiségből - álló magánkápolnát is gyakran létesítettek a 18-19. században. A 18. század végétől a házikápolnák hagyományos funkcionalitása megmaradt, de léptékük jelentősen szerényebb lett.

\footnotetext{
${ }^{29}$ Borovszky. Somogy 113, 122, 336, 342.
} 
1701-1722 között Savoyai Jenő (1663-1736) herceg számára Johann Lucas von Hildebrandt (1668-1745) építész tervei nyomán épült kastély Ráckevén. ${ }^{30}$

A kastély kis házikápolnája (15.a ábra) a kastély északnyugati szárnyának földszintjén kapott helyet; közelében a fogadóudvar felől külső bejárat nyílt. A kápolna belső megközelítése a nyugatra tájolt oltárral szemben, a folyosóról volt lehetséges. A helyiség déli oldalához egy tágas előtérből nyíló oratórium kapcsolódott, amely széles nyílással engedett belátást a kápolnatérbe.

A pápai régi várat gróf Esterházy Ferenc (1683-1754) 1731 körül restauráltatta, majd 1740-1758 között újjáépíttette Franz Anton Pilgram (1699-1761) tervei alapján. A keleti szárny déli részén 1754-ben készült el az Aranyos Szent Kereszt tiszteletére szentelt kápolna $(15 . b-c a ́ b r a)$.

A kápolna az emelet helyiségsorában, a mulató nyári ház közelében kapott helyet oly módon, hogy az a fogadóudvar mentén futó oldalfolyosóról és az egymásba nyíló termek sorából is egyaránt megközelíthető volt. A kápolna oltára az északi falra került, emögött sekrestyét, a déli oldalon oratóriumot helyeztek el.

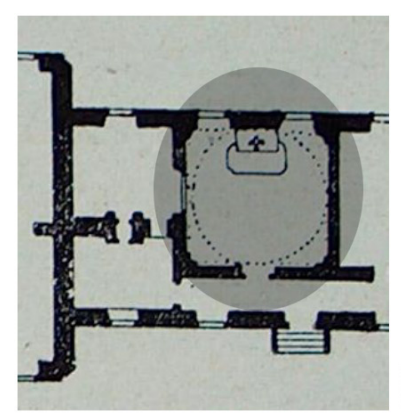

a)

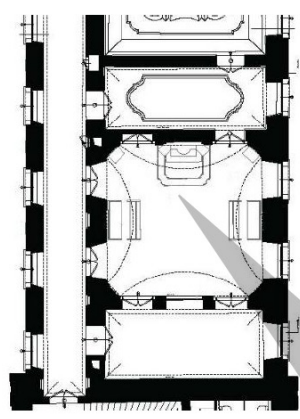

b)

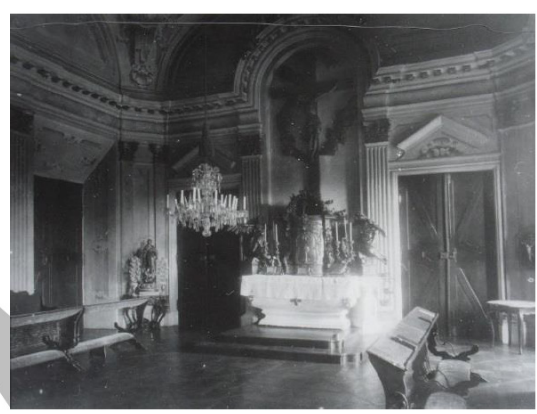

c)

15. ábra. Magánkápolnák példái: a) Ráckeve; Pápa $b$ ) a kápolna alaprajza, $c$ ) belső képe

Habsburg József (1776-1847) föherceg, Magyarország nádora (1796-1847) Alcsúton Pollack Mihály (1773-1855) tervei alapján 1819-1826 között építtetett teljesen új kastélyt. ${ }^{31}$ A kastély szúkszavú, korabeli leírása ${ }^{32}$ Novák Dániel ,architectustól” 1836-ból, számos belső fényképfelvétele pedig már József Károly Lajos (1833-1905) föherceg korából, a századfordulóról maradt fenn, valamint az 18701871. évi felmérés és az 1920 -as évekbeli alaprajz ismert. ${ }^{33}$

\footnotetext{
${ }^{30}$ A ráckevei kastélyról 1. Ybl 1924. 51-80; Rados 1939. 40-41; Rados 1985. 16-29; Dercsényi-Koppány 1999. 120; Aggházy-Bán 1958. 29-31; Hegedüs 1984.

${ }^{31}$ Soós 2002. 42.

32 Novák 1836.1. 231, 235.

${ }^{33}$ Rados 1931. 229. 230. ábra.
} 
A kastély első kápolnája (16.a ábra) a déli szárny emeletének szobasorában helyezkedett el. Az oltár a fogadóudvar mentén futó oldalfolyosóról nyíló ajtóval szemben, a déli homlokzat két ablaka között kapott helyet. Mellette, nyugat felé nyílt a sekrestye, északi oldalán egy kisebb konyhaelőtér húzódott a folyosó felé. Az 1870-1871. évi felmérés a kápolna áthelyezését mutatja, amely során néhány helyiséggel keletebbre, hasonló diszpozícióba építették át. Ebben a kápolnában fütés is volt, nyugati falán - a sekrestyeajtó mellett - kályha állt.

A 18. századi sajátos diszpozíció és funkcionális kapcsolat, tehát a tulajdonosi lakosztályoktól távolabbi, az épületszárnyak végére, így az elsődleges forgalmi kapcsolatokból kieső, esetenként a vendéglakrészekhez kapcsolódó, „,perifériás” elhelyezés az 1850-es évektől ismét elterjedt, biztosítva a házikápolnák elkülönítését a mindennapi élet zajától, a közösségi helyiségek forgatagától. ${ }^{34}$

Csákváron gróf Esterházy János (1747-1800) Fellner Jakab (1722-1780) tervei szerint 1778-1781 között kibővített kastélya délkeleti szárnyának földszintjén alakítottak ki kápolnát, amelyet az 1816-1823 közötti átépítéskor megszüntettek (16.b ábra).

A kápolna a fogadóudvar mentén futó folyosóról volt megközelíthető, főoltára a délkeleti falon, a bejárattal szemben kapott helyet. A kápolna délnyugati oldalán közvetlen kijárat is nyílt, amely a déli, vendéglakrészeket befogadó mellékszárny és a tulajdonosi lakosztályok elhelyezésére szolgáló föépület közötti szük udvarba vezetett. Sekrestye és oratórium nem tartozott a kápolnához.

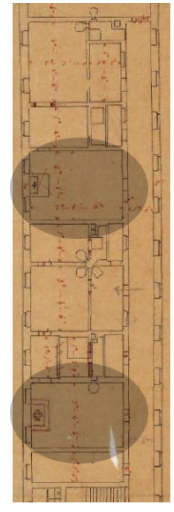

a)

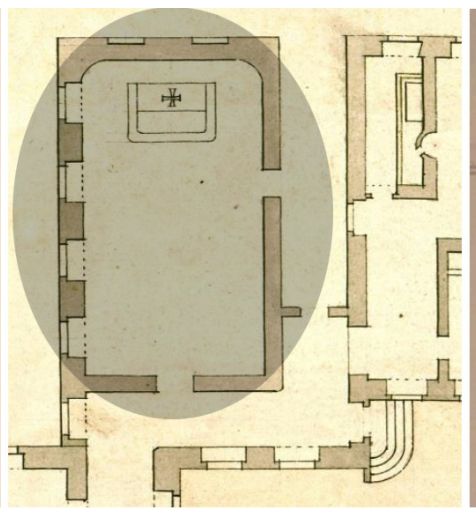

b)

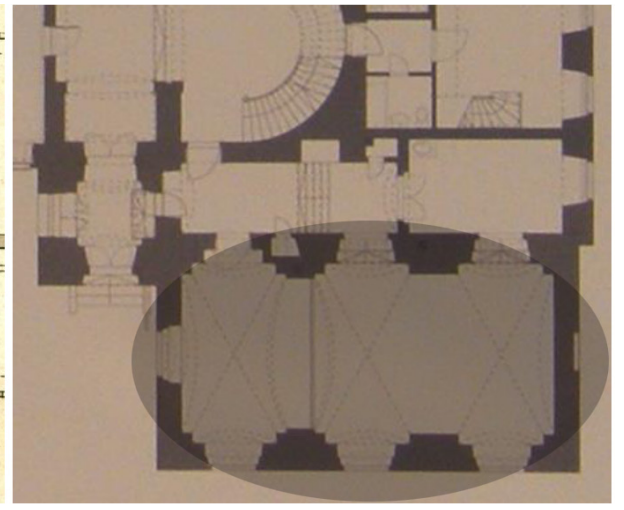

c)

16. ábra. Magánkápolnák példái: a) Alcsút; b) Csákvár; c) Fehérvárcsurgó

Fehérvárcsurgón gróf Károlyi György (1802-1877) megbízásából az 1844-1851 közötti, Heinrich Koch és Ybl Miklós építészek által tervezett bővítés során épült házikápolna (16.c ábra).

\footnotetext{
${ }^{34}$ Sisa 2007. 74.
} 
A kápolna - kis emelt oratóriummal - a kastély északnyugati szárnyának végén, az új sarokpavilonban kapott helyet, közelében toronnyal. A kápolna és az oratórium belső folyosókon volt megközelíthető, amelyekre udvari bejárat is vezetett. A délnyugatra tájolt oltár mellett sekrestye kapott helyet, amely szintén megközelíthető volt a belső folyosóról.

Nagyhörcsökpusztán gróf Zichy Ferenc Pál (1822-1909) és neje, gróf Kornis Anna (1836-1901) megbízásából 1853-1858 között felépült ${ }^{35}$ nagyszabású kastélyának átalakítását Ybl Miklós (1814-1891), majd Gottfried Semper (1803-1879) építészek megbízásával többször tervezték. ${ }^{36}$ Az 1870-1873 között csak részben megvalósult átalakítás nagyszabású tervsorozata (17. ábra) a kastély déli mellékszárnyát is érintette.

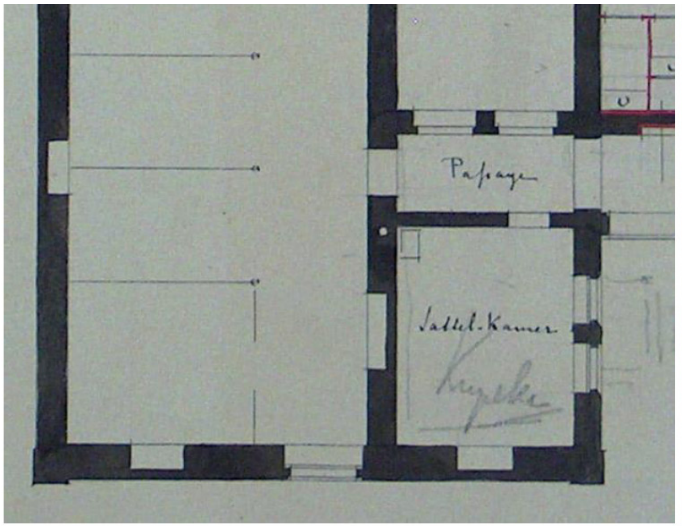

a)

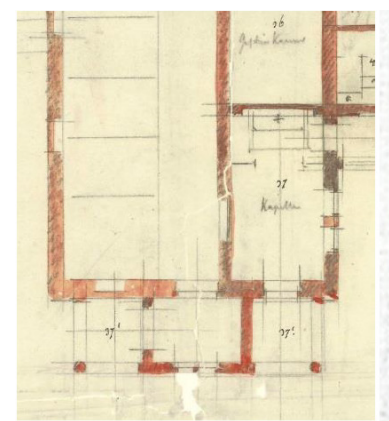

c)

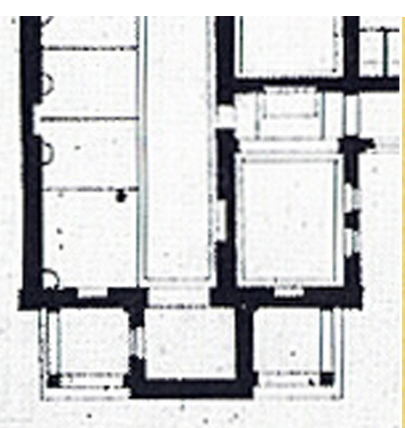

d)

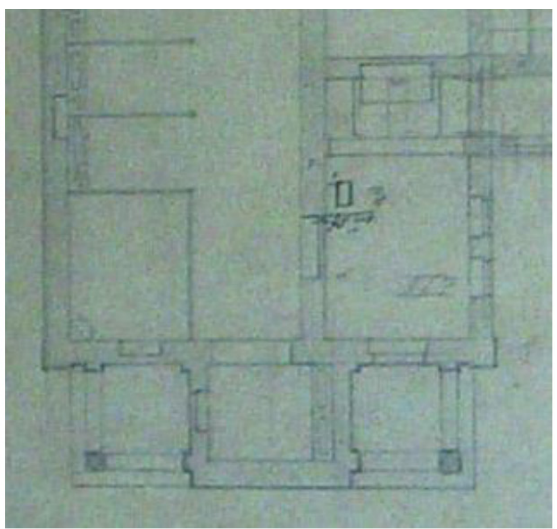

b)

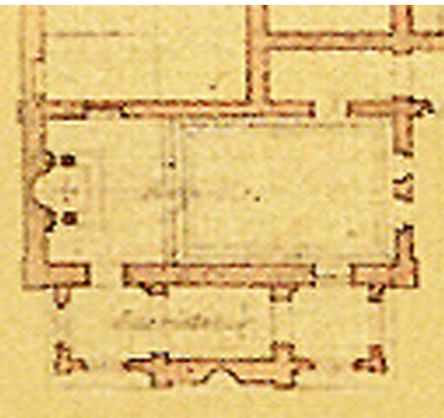

e)

17. ábra. Nagyhörcsökpuszta: a) a kastélykápolna tervezett helyén lévő helyiségek az új funkció ráírásával, b) kézrajzi vázlat, c) első tervváltozat a kastélykápolna kialakítására, d) tisztázott alaprajz, e) a kápolna elhelyezésének meg nem valósult tervváltozata

${ }^{35}$ Sisa 1985. 1-9.

${ }^{36}$ Sisa 2004. 333. 


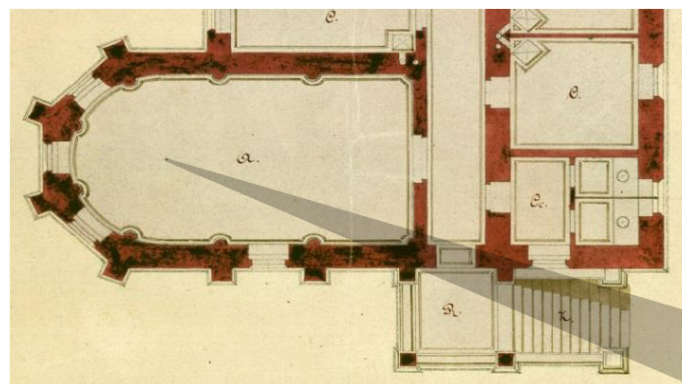

a)

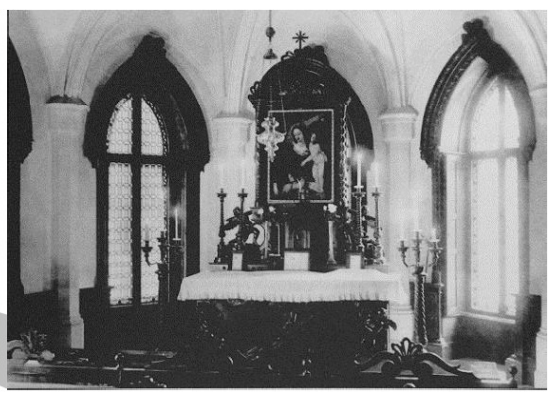

b)

18. ábra. Nádasdladány: a) a kápolna alaprajza, b) a kápolna belső képe

Gróf Nádasdy IX. Ferenc (1842-1907) 1873-1876 között Linzbauer István (1838-1880) tervei szerint kiépített sárladányi (ma Nádasdladány) kastélyának kápolnája az északi szárny nyugati végén épült. ${ }^{37}$

A házikápolna (18. ábra) bejárata a vendéglakrészek sorát feltáró folyosóról nyílt, amelyre nyugati végén homlokzati előépítménnyel hangsúlyozott külső bejárat vezetett. A Szent Családoltár az észak felé kialakított, háromszögü apszisban állt. A kápolnához sekrestye nem tartozott.

Az alcsúti kastélyt a 19. század második felében több ütemben bővítették. Ezek közül - a házikápolna létesítése szempontjából - jelentős a Habsburg Károly Lajos (1833-1905) föherceg megbízásából 1879-1880 között Stornó Ferenc (1821-1907) tervei szerint készült átépítés, amelynek során a ma is létező új kápolna (19. ábra) létesült. Simor János (1813-1891) esztergomi érseknek egy alcsúti látogatása alkalmával felkeltette a figyelmét az északi oldalszárnyban elhelyezett istálló kialakítása, és megjegyezte, hogy annak épülete olyan szép, hogy kápolnává is átalakítható lenne. Ez adta az ötletet a föhercegnek ahhoz, hogy otthonában az addigi - a fóépület déli

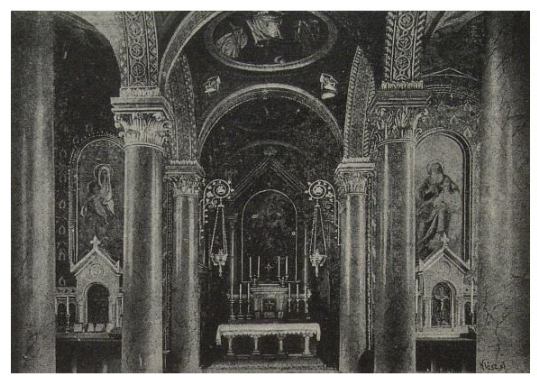

a)

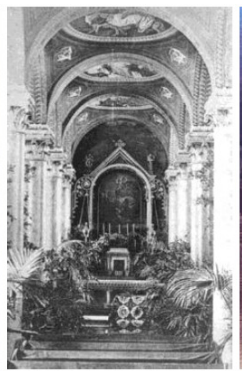

b)

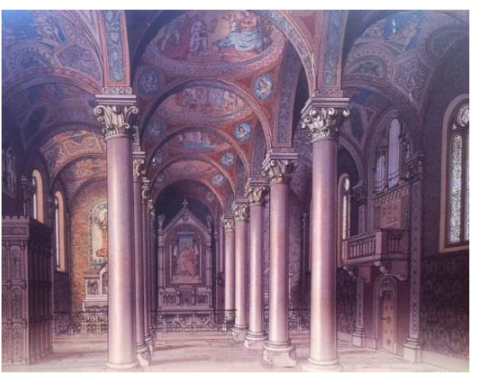

c)

19. ábra. Alcsút: $a$ ) az új kápolna belső látképe, b) az oltár, c) a csarnoktér belső képe

${ }^{37}$ Sisa 2004. 
szárnyában lévő - kis kápolna helyett egy nagyobbat alakíttasson ki. A kápolnát 1880. november 27-én Pauer János (1814-1889) székesfehérvári püspök szentelte fel, aki Kruesz Károly (1819-1885) pannonhalmi főapáttal és Pellet Ödön (18331896) székesfehérvári kanonokkal érkezett meg Alcsútra. A kápolna megáldása után díszebéd volt a vendégek számára. ${ }^{38}$

Az északi szárnyban eredetileg elhelyezett istállóból létesült kápolna tere megőrizte az istálló háromhajós, oszlopsorral tagolt kialakítását. A főoltár a középső hajó nyugati oldalára került a déli hosszoldal tengelyébe, a reprezentatív bejárat erre a tengelyre merőlegesen, az előudvar felől nyílt. A félemelet magasságában lévő oratóriumba a kastély folyosóin keresztül lehetett eljutni. Az ajtóhoz néhány lépcső vezetett. Az oratórium középső részének kápolnába néző ablakai nyithatóak voltak. Az oratórium bal oldali részén az udvarhölgyek és a föhercegi udvartartás tagjai foglaltak helyet. ${ }^{39}$ A kápolna a keleti oldalon a konyhaszárnyhoz kapcsolódott, nyugati oldalán nem sokkal a kápolna kialakítása után - annak folytatásaként a szárny végén - két nagy teremböl álló könyvtár- és levéltárépületet emeltek.

A házikápolnák épületen belüli diszpozíciójában a 18. század végétől a fóbejárathoz vagy a fölépcsőházhoz közeli elhelyezést is alkalmazták, amely a 19. század első feléig volt jellemző. Ennél a megoldásnál a házikápolna funkcionálisan hangsúlyt kapott, a főbejárat és a reprezentatív közlekedés tereihez kapcsolódott.

Gróf Batthyány Tivadar (1729-1812) 1796-1799-ben valószínúleg Hild János tervei szerint építtette ki a korábbi, 1754-1755-ben épült bicskei kastélyt, amelynek alaprajza fennmaradt (20.a ábra).

A kastély első kápolnája az északkeleti szárny közepén, a fogadóudvarról megközelíthető főlépcsőház mögött, a földszinten helyezkedett el. Az első lépcsőforduló pihenőjéről megközelíthető kis egyablakos helyiségben az oltár a délkeleti rövidebb fal előtt állt. Sekrestye nem tartozott a kápolnához. A kastély teljes átépítése során a kápolna továbbra is a földszintre, de új helyre került az északkeleti kocsiáthajtó kapualj mellé (20.b-c ábra). A kápolna bejárata a kapualjhoz csatlakozó oldalfolyosóról nyílt, az új elhelyezkedésủ oltárt keletre tájolták.

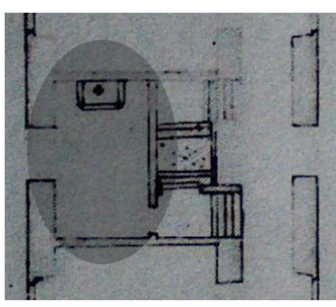

a)

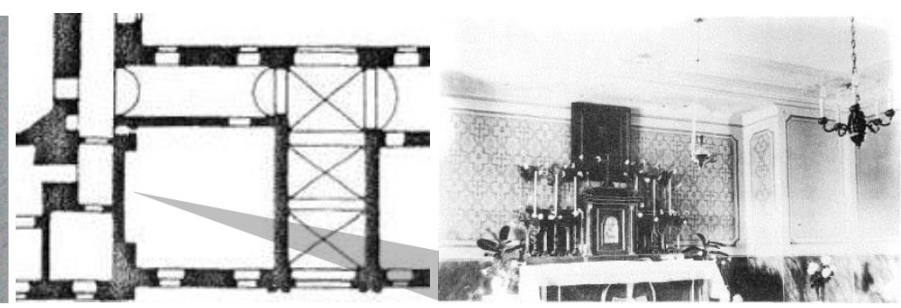

b) c)

20. ábra. Bicske: a) a régi kápolna alaprajza, $b$ ) az új kápolna alaprajza, c) az új kápolna belső képe

\footnotetext{
${ }^{38}$ VU XXVII (1880) 49. 809; Óhidy 2007. 201.

${ }^{39}$ Óhidy 2007. 202.
} 


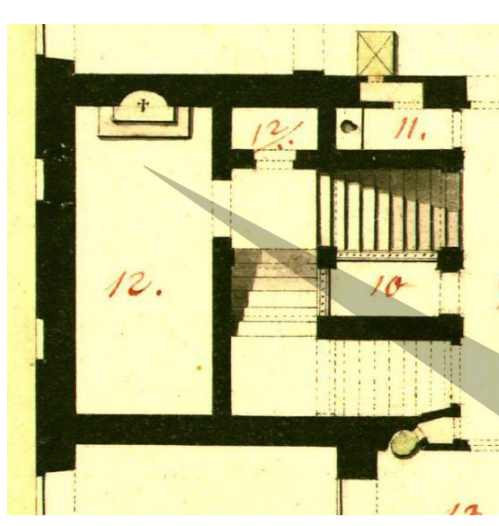

a)

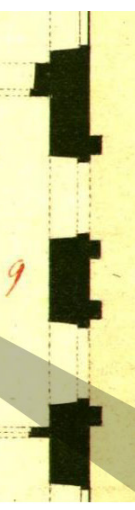

21. ábra.

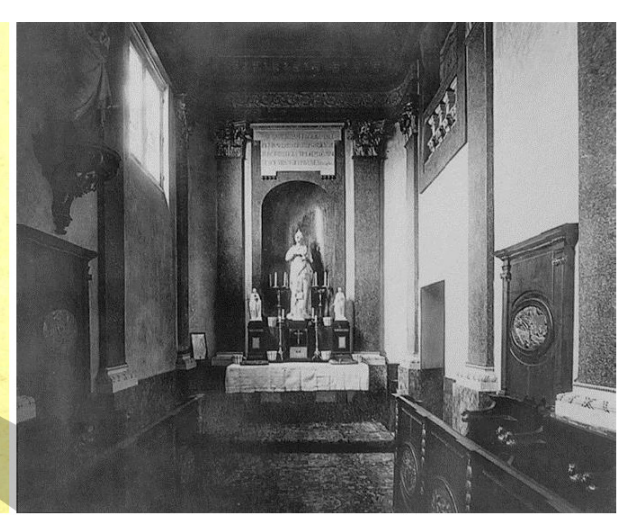

b)

bra. Keszthely: a) a kápolna alaprajza, b) belső képe

Tolnai Festetics Kristóf, majd fia, Pál (1722-1782) keszthelyi kastélyának 1782 és 1811 közötti inventáriumai, ${ }^{40}$ tervrajzai és felmérései jórészt fennmaradtak. Az 18071808. évi - az átalakítás idején felvett - leltár szerint Festetics György (1755-1819) gróf és felesége részben a korábbi férfi lakosztály helyét elfoglaló közös lakosztályban lakott, közvetlen szomszédságban fiuk új lakrészével.

A Szent Zsófia tiszteletére 1804-ben felszentelt, kétszintes kápolna (Kápolyna) (21. ábra) az új déli szárnyban kapott helyet a hajdani grófkisasszonyi szobából átalakított emeleti oratóriummal (Chorus). Ezzel szemben, a nyugati fal előtt kapott helyet az oltár, tőle jobbra a kápolna bejárata az új lépcsőházból nyílt. A bejárat közelében a lépcsőpihenőről megközelíthetően, a sekrestye céljaira egy kis helyiséget (Szekresztye) alakítottak ki. A Festetics család és a kastély személyzete számára a kápolnában rendszeresen tartottak misét, amelyet a család az oratóriumban, a személyzet a kápolnában hallgatott. „A püspöki engedély szerint a kápolnában minden vasár- és ünnepnapon szabad misézni világi papnak és szerzetesnek egyaránt. [...] A szent misét az apátplébános és a segédlelkészek szokták tartani. [...] A grófi család a szent misét művészi alkotásu képekkel diszitett oratoriumban, a kastély tiszti személyzete és cselédsége a kápolnában hallgatja."

Gróf Sándor Móric (1805-1878) számára a bajnai kastély 1834-1842 közötti, Hild József (1789-1867) tervezte átalakítása során alakítottak ki házikápolnát (22. ábra).

A kápolna a földszinten, egyrészt a fogadóudvarról nyíló, 18. századi kocsiáthajtóból kialakított előcsarnokból közvetlenül volt megközelíthető a délkeletre tájolt oltár mellett, másrészt az oltárral szemben a földszinti lakószobák sorából. A kápolna délnyugati oldalán kis folyosó húzódott.

\footnotetext{
${ }^{40} \mathrm{Az}$ 1782. évi leltárak feldolgozásait, továbbá a kastély berendezését ismertette Péczely 1958.

${ }^{41}$ Bontz 1896. 353.
} 


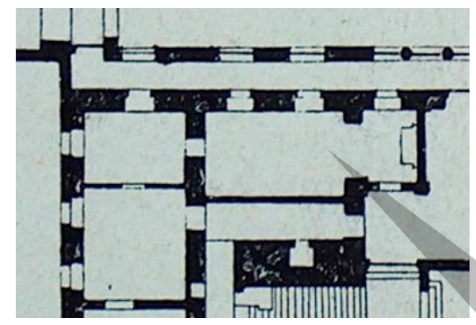

a)

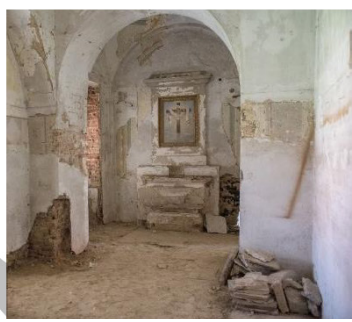

b)

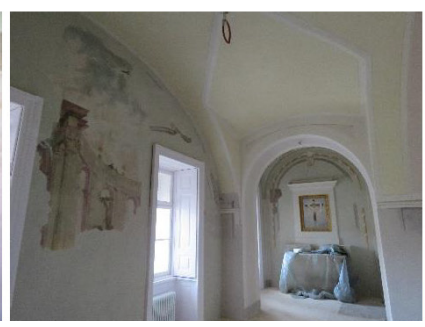

c)

22. ábra. Bajna: a) a kápolna alaprajza, b) belső képe a restaurálás előtt, c) a kápolna a restaurálás idején

Pollack Ágoston (1807-1872) és Ybl Miklós 1843. évi fóti kastélyterve - amely valószínűleg Károlyi István (1797-1881) gróf megbízásából készült - fennmaradt (23.a ábra).

A házikápolna a terven az oltár ábrázolásáról azonosítható. A kápolna földszinti elhelyezése hangsúlyos: a tágas elöcsarnokból nyílik közvetlenül; a bejárati oldalon kis emelt oratóriummal.

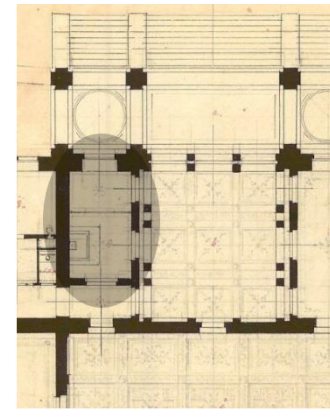

a)

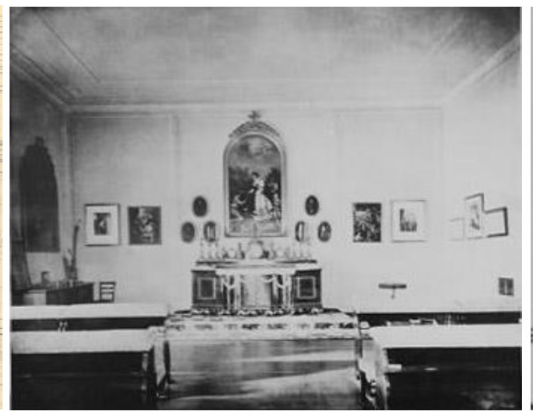

b)

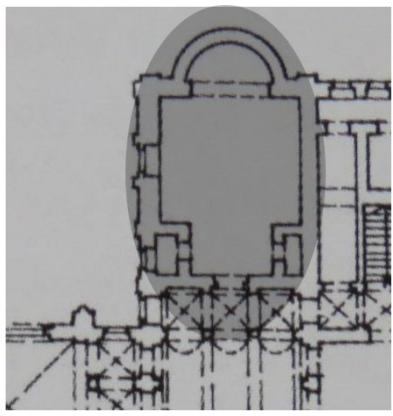

c)

23. ábra. Magánkápolnák példái: Fót: a) a kápolna tervezett alaprajza, b) a megvalósult kápolna belső képe; c) Vasvörösvár, a kápolna alaprajza

Az 1860-as évektől érzékelhető diszpozíciós újítás a házikápolnának a társasági terek monumentális csoportjához történő hangsúlyos kapcsolása volt, biztosítva ugyanakkor egy közvetlen külső megközelítés lehetőségét is, amely révén a kápolna forgalma - a 18. századi példákhoz hasonlóan - ismét differenciálttá vált.

Gróf Erdődy István (1813-1896) Wéber Antal (1823-1889) tervei szerint 18621866 között építtetett kastélyt Vasvörösvár (ma Rotenturm an der Pinka, Ausztria) területén. Ezt gróf Erdődy Gyula (1845-1917) 1900 körül a belsőben átalakíttatta. Az épület belső tereit 1924-ben tüzvész pusztította. ${ }^{42}$

\footnotetext{
${ }^{42}$ Sisa 2007. 166-168.
} 
A kastély nyugati sarkának földszintjén elhelyezett kápolna (23.c ábra) a föbejárat közelében található. A délnyugati oldalán a fogadóudvarról közvetlen külső bejárat, a központi nagy csarnok előteréből belső bejárata nyílik, északi oldalán az emeletre felvezető főlépcsőház kapott helyet. A kápolna északnyugatra tájolt oltára félköríves apszisban állt.

Az Ybl Miklós (1814-1891) építész által a Békés megyei Ókígyóson Wenckheim Frigyes (1842-1912) grófnak 1875-1879-ben tervezett kastélykápolnája jelentős változást mutatott a tervezés és megvalósulás folyamatában.

A kastély korai tervváltozatain a kápolna az épület nyugati oldalán, a föépülethez nyaktaggal kapcsolt földszintes épülettömegként jelent meg, amelyet e nyaktagon keresztül lehetett megközelíteni. A nyugatra tájolt oltárt félköríves apszis hangsúlyozta volna (24.a ábra). Egy későbbi helyszínrajzon - a megvalósult állapottal azonos módon - a hasonló kialakítású kápolna már a kastély keleti oldalán jelenik meg, keletre tájolt oltárral és az azt hangsúlyozó apszissal (24.b-c ábra). A kápolna bejárata észak felől, az udvarról nyílik, de a kastélyból is biztosított megközelíthetőséget, amely révén a kápolna a földszinti társasági terek monumentális sorához közel, a fölépcsőházból is megközelíthetővé vált.

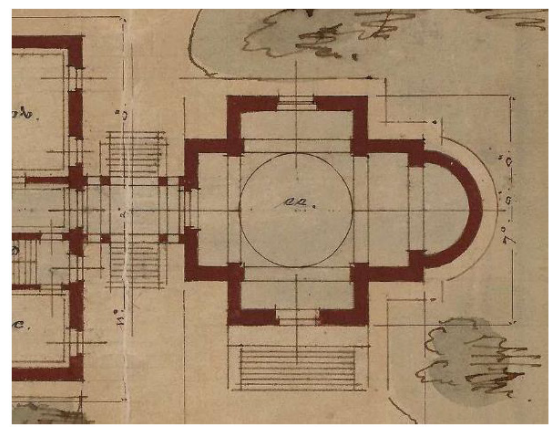

a)

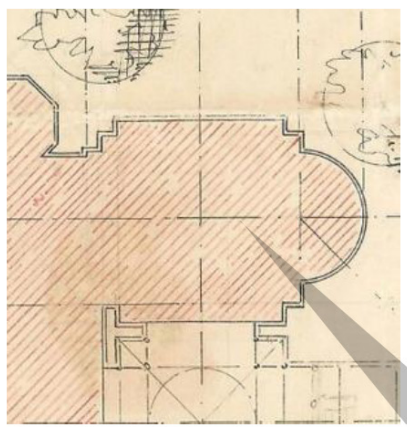

b)

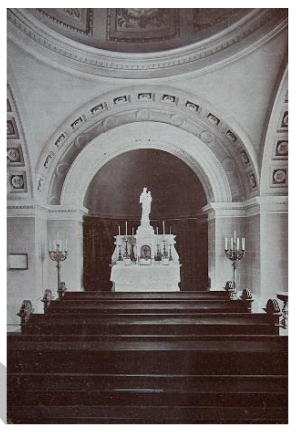

c)

24. ábra. Ókígyós: a) a kápolna tervezett alaprajzi ábrázolása, b) a kápolna megvalósult elhelyezésének helyszínrajza, c) belső képe

Budapesten az Egyetem utcai (ma Károlyi Mihály u. 16. szám alatti) régi Károlyipalota belső átalakítására gróf Károlyi Gyula (1837-1890) megbízásából 1880 körül került sor. ${ }^{43} \mathrm{Az}$ új kápolna fényképe fennmaradt (25.b ábra).

A kápolnát az északi oldalszárnyba vezető folyosó első szakaszából választották le, így annak előterét a télikert adta, amely közvetlenül kapcsolódott a társasági termek (szalonok) sorához.

${ }^{43}$ Óhidy 2007. 200. 


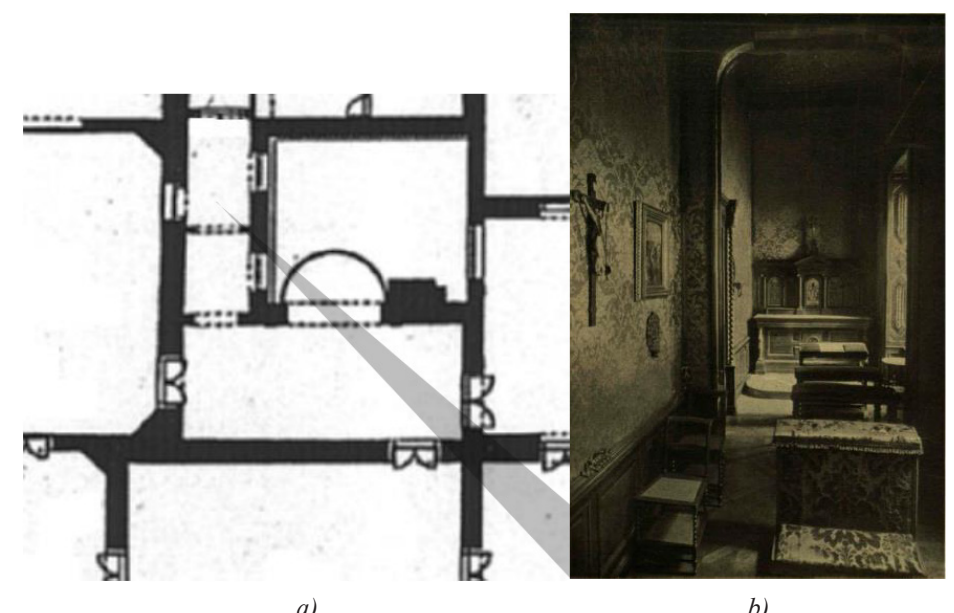

25. ábra. Az Egyetem utcai Károlyi-palota kápolnája: a) alaprajz, b) belső kép

\section{A HÁZIKÁPOLNÁK SORSA ÉS BEMUTATÁSUK LEHETŐSÉGEI}

A foúri lakóhelyek 19-20. századi funkcióváltozásai Magyarországon a legtöbb esetben sajnálatosan a házikápolnák valamilyen mértékü pusztulásával jártak. A kápolnaberendezések, szakrális felszerelések széthordása általános jelenség volt, ugyanakkor a pusztítás magasabb fokán a kápolna építészeti tere sérült meg a díszítmények és architektonikus tagolások eltávolításával, végső soron pedig az építészeti tér egysége bomlott meg a válaszfalakkal, födémekkel történő fel- és megosztással, amely révén számos esetben nemcsak a szakrális jelleg szünt meg, hanem a történeti tér is felismerhetetlenné vált.

A ráckevei és az óbudai kastélyt már a 19. században elhagyták, raktárként szolgáltak, az 1950-es években pedig szükséglakásokat létesítettek a hajdan reprezentatív épületekben. Az edelényi kastélyt 1912-től a Bódvavölgyi Bányatársaság bérelte, amely jelentős, a belső tereket romboló átalakításokat végzett: 1921-ben a kastély kápolnáját egy födémmel kettéosztották és helyén lakásokat alakítottak ki, az emeleti részhez falépcsőt építettek. ${ }^{44}$ A körmendi kápolna gazdag stukkódíszeit 1957-ben - a kastély kollégiummá alakítása során - leverték, terét később födém beépítésével osztották meg. A Budapest 1944 karácsonyától 1945. február 11-ig tartó ostroma során teljesen kiégett királyi palota kápolnájának megmaradt, de jelentősen sérült elemeit 1954 és 1957 között elhordták (,átmentették”, illetve építőanyagként eladták ${ }^{45}$ ), majd a kápolna terét 1959 és 1967 között radikálisan átépítették osztófödémek

${ }^{44}$ Tóth-Bay 2014. 11-12.

${ }^{45}$ Historia Domus. A plébániatemplom oltárának története. Vörösvári Újság IV (2004) 7. sz. (http:// pilisvorosvar.hu/vorosvariujsag-regi/2004/julius/7.htm (Utolsó megtekintés: 2019. 10. 29.) 


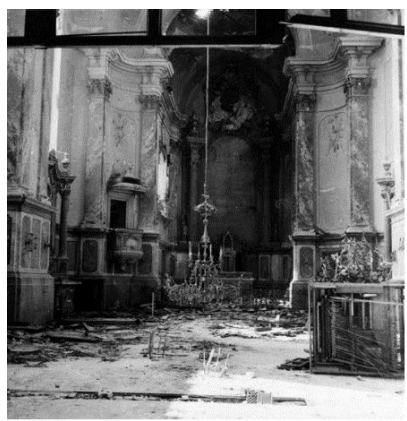

a)

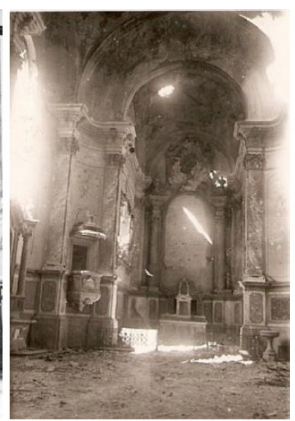

b)

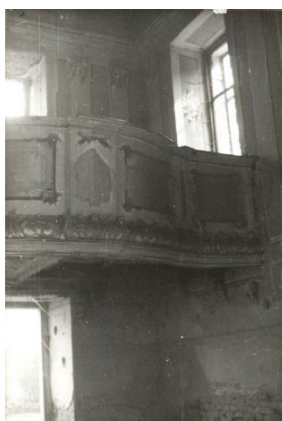

c)

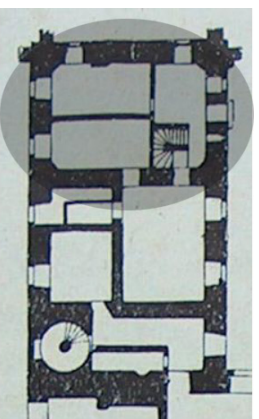

d)

26. ábra. Kápolnasorsok a II. világháború után: Budavár: a) belső kép az ostrom után, b) belső kép a romeltakarítást követöen; $c$ ) Nagycenk; d) Edelény

beépítésével, a nyílásrend megváltoztatásával, a belső tértagolás sematizálásával, modernizálásával. Nagycenken 1945 után a kápolna felszerelése a kastéllyal és berendezésének egy részével együtt elpusztult. Az 1970-es évek elején átépítették a hajdani kápolna belső terét is, az addig egységes történeti teret egy utólagosan beépített födémmel kettéosztották. A kialakított két szinten többek között irodákat, lakásokat, illetve egy restaurátormühelyt alakítottak ki. Az 1980-as években újra változtattak belső elrendezésén, az emeleten egy közösségi teret hoztak létre, mosdókat alakítottak ki (26. ábra).

A malackai (ma Malacky, Szlovákia) hajdani Pálffy-kastélyban 1957 után kórházat létesítettek. Az átalakítások során a Szent Kereszt tiszteletére szentelt, a kastély északi sarkában lévő kápolnát - amely 1934 után az itt elhelyezett gimnázium számára is szolgált - megszüntették: a belső térbe födémeket és válaszfalakat építettek. Ennek kialakítása azonban eltért a korszakban megszokott, pusztító megoldásoktól, ugyanis az oltár elé köpenyfalat húztak biztosítva annak fennmaradását. Később, a kastély müemléki kutatása során e falat megbontva „megtalálták” az északnyugati falon elhelyezett keresztet és annak architektonikus keretezését. A válaszfalakat és az osztófödémet kibontva 2016-ban helyreállították a kápolna történeti terének egységét (27. ábra).

Egy-egy történeti tér- vagy foúri rendeltetésegység gyakorlati rekonstrukciójának első példái az 1980-as évek kastélykápolna-helyreállításai voltak hazánkban. Ezek esetében az elvi rekonstrukciót (a rendeltetés visszaállításával vagy anélkül) gyakorlati helyreállítás is követte. Körmenden 1988-ban a kastély északnyugati sarokbástyájában elhelyezkedő, három szintet átfogó légterü, de 1962-ben egy födémmel megosztott, hajdani kápolnáját - mủemléki kutatás és feltárás után - rekonstruálták, visszaállítva, majd bemutatva a gazdag barokk stukkó- és falpillér-architektúrát (28. ábra). 


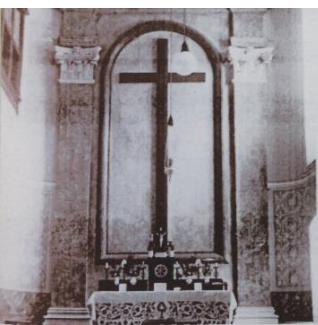

a)

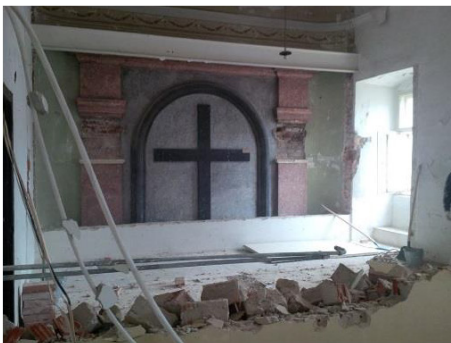

d)

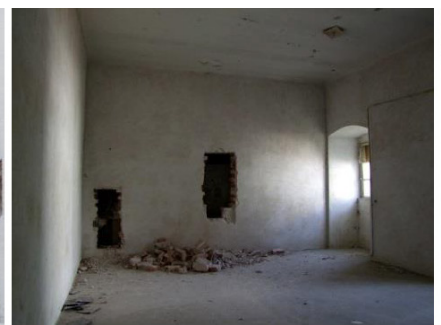

b)

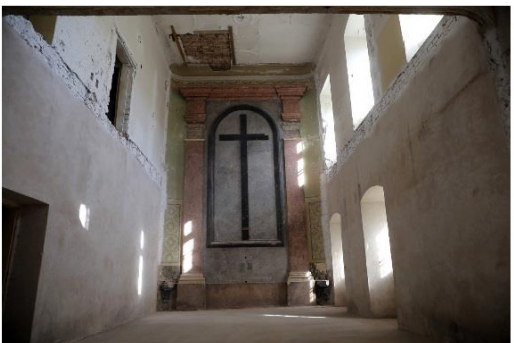

e)

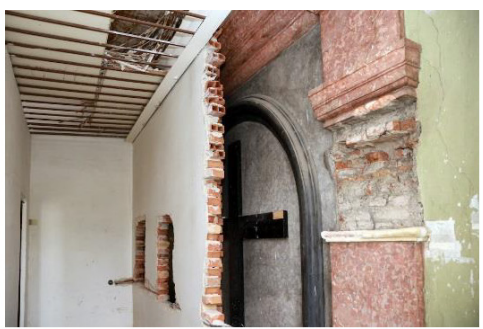

c)

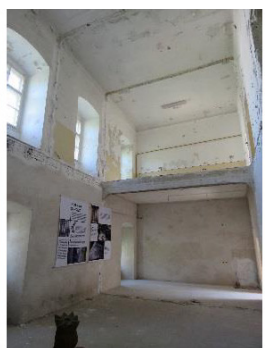

f)

27. ábra. Malacka, a kastélykápolna $a$ ) archív képe, $b$ )-d) feltárásának állapotfotói, e)-f) a kápolna belső terének helyreállított egysége

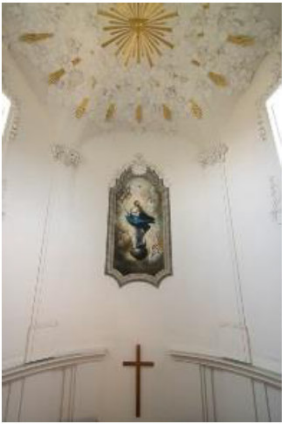

a)

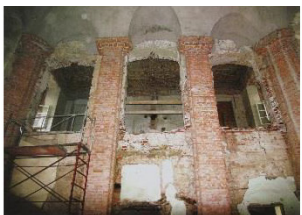

d)

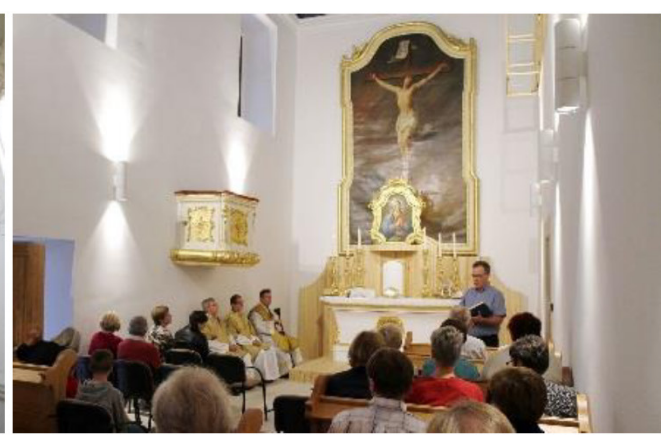

b)

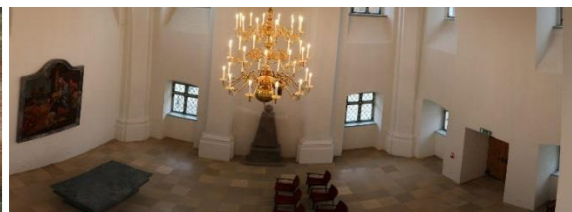

e)

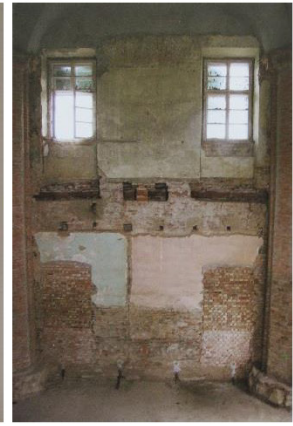

c)

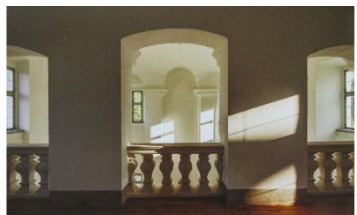

f)

28. ábra. Helyreállított kastélykápolnák: a) Körmend; b) Nagycenk; c)-f) Edelény 


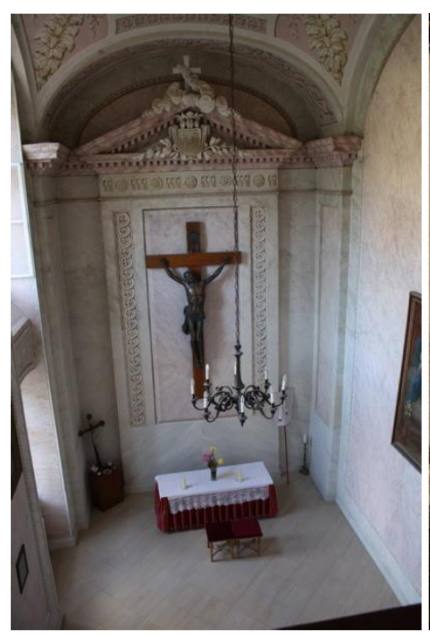

a)

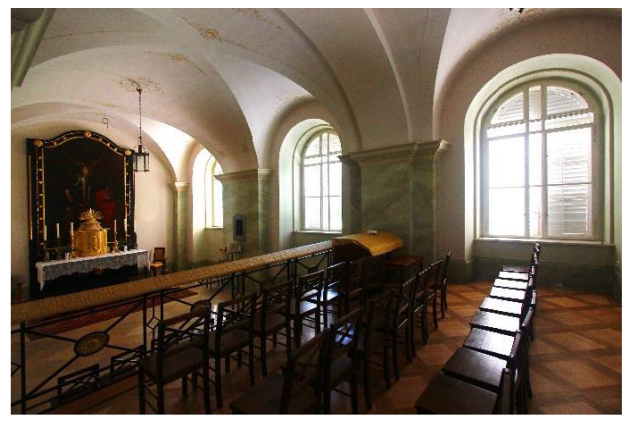

d)

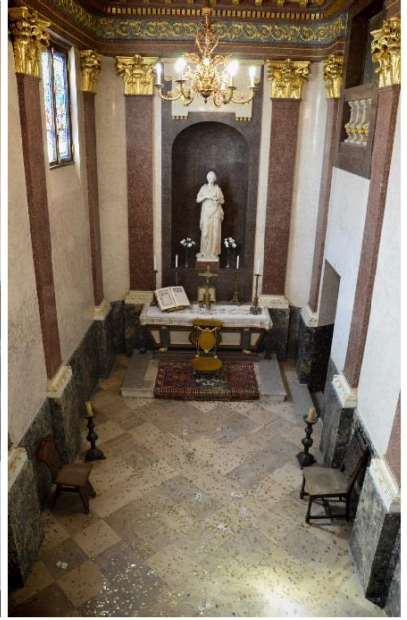

b)

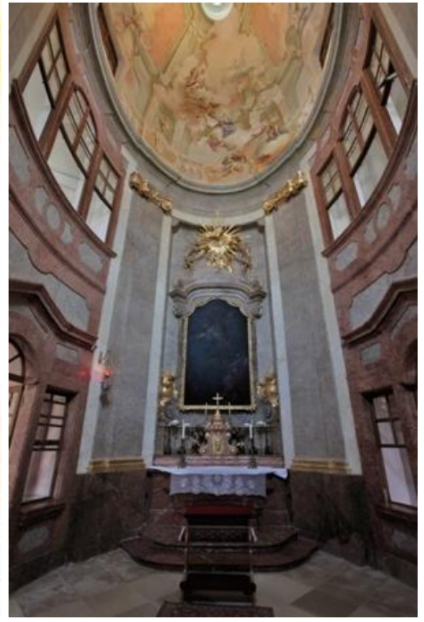

c)

29. ábra. Helyreállított kastélykápolnák:

a) Hőgyész; $b$ ) Keszthely; c) Eszterháza; $d$ ) Fehérvárcsurgó; $e$ ) Pápa

2014-ben helyreállították az edelényi, 2016-ban pedig a nagycenki kastély házikápolnájának történeti terét is, a szakrális berendezés megmaradt elemeinek (anastylosis) visszaállításával biztosítva a történeti rendeltetés megjelenítését, illetve az eredeti funkciónak megfelelö térhasználatot (29. ábra).

Azokban az épületekben (pl. Hőgyész, Monok, Pápa, Keszthely, Fertőd kastélyai), amelyekben a hajdani kápolna - esetenként funkcióját veszítve, de - fennmaradt, a történeti tér megmaradt, a helyreállítás restaurátori feladatokkal végezhető el, az eredeti funkció és térhasználat a bútorozás és szakrális felszerelés visszaállításával, illetve rekonstrukcióval mutatható be. A korszerü helyreállítást pedig a kápolna (ismételt) felszentelésének ünnepi aktusa zárja. 
Összefoglalva: A házikápolna a világi föúri lakóhelyek fontos szakrális rendeltetése volt, amelynek építészeti jelentőségét az adja, hogy a történeti térkompozíció egyrészt a liturgia egyszerüsített változatára specializálódott, ugyanakkor a föúri és köznépi együttes jelenlét funkciója térben gazdagon tagolt, differenciált kialakítást (oltár, szentély, oratórium-karzat, belső csigalépcső, külső bejárati előtér stb.) eredményezett az épületen belüli, igen változatos diszpozíciós megoldások és funkcionális kapcsolatok mellett. A házikápolna fontosságát a vizsgált korszakban nemcsak az építtető foúr vallási attitűdjének reprezentációja, a köznép számára imahelyet biztosító kegyúri kötelesség teljesítése adta, hanem az is, hogy a foúri házikápolnákban az uralkodó vallásossága is kifejeződhetett, amelyet a király személyének való erős megfelelési vágy eredményezhetett. A mélyen katolikus Mária Terézia uralkodásának idején a fớri házikápolnák épületen belüli hangsúlyos elhelyezése, nagyléptékü kialakítása volt látható. Fia, II. József felvilágosult vallásosságában a vallások egyenjogúsága és szabadsága, valamint az állam fennhatósága a vallások felett, sarkalatos elvek voltak. A liberális szellemü II. Lipót, majd I. Ferenc és V. Ferdinánd magyar királyok idején a katolikus vallási buzgalom kifejeződésének további háttérbe szorulásával párhuzamosan került a szakrális rendeltetés a vendéglakrészek építészetileg hangsúlytalan, a tulajdonosi lakosztályoktól és a közösségi terektől távoli épületrészébe. I. Ferenc József király munkabírása, mély vallásossága és uralkodói hivatástudata egyaránt legendás volt, uralkodása alatt pedig a házikápolnák ismét reprezentatív kialakítással, hangsúlyos építészeti diszpozícióval jelentek meg a monumentális társasági tércsoport direkt vagy indirekt térkapcsolatában. A foúri lakóhelyek 19-20. századi funkcióváltozásai azonban sok esetben a házikápolnák pusztulásával jártak, amelynek következtében müemléki kutatásuk falkutatási módszerekkel, roncsolásos feltárásokkal lehetséges, és mủemléki helyreállításuk, életmódtörténeti bemutatásuk is csak a rekonstrukció alkalmazott módszerével valósítható meg.

\section{IRODALOM}

Aggházy-Bán 1958

Baji-Csorba 1994

Balázs-Kézdy 2001

Bontz 1896

Borovszky.Pest-Pilis

Borovszky.Somogy

Bugár-Mészáros 1997
Aggházy Mária - Bán Attila: Pest megye müemlékei. II. köt. Akadémiai Kiadó, Budapest 1958. (Mtop V.)

Baji Etelka - Csorba László: Kastélyok és mágnások. Az arisztokrácia világa a századvégi Magyarországon. HG \& Társa Kiadó, Budapest 1994. Balázs János - Kézdy Éva: „Harmonia Dignitatis”. Az értékrend vizsgálata főnemesi családok leszármazottainak körében. Századvég. Új Folyam (2001) 21. http://www.c3.hu/scripta/szazadveg/21/balazs.htm (Utolsó megtekintés: 2019. 07. 10.)

Bontz József: Keszthely város monográfiája. Keszthely 1896.

Borovszky Samu: Pest-Pilis-Solt-Kiskun vármegye. I. kötet. OMT, Budapest é. n. [1910] (Magyarország vármegyéi és városai)

Borovszky Samu: Somogy vármegye. OMT, Budapest [é. n.] (Magyarország vármegyéi és városai.)

Bugár-Mészáros Károly: A nádasdladányi Nádasdy-kastély múltja, jelene és jövője. MÁG, 1997. (Gépirat.) 
Cs. Dobrovits 1983

Csorna 1966

Dávid 2000

Dávid 2002

Dercsényi-Koppány 1999

G. Lászay 1994

Gál 1992

Galavics 1992

Galavics 2000

Gerő 1955

Gudenus-Szentirmay 1989

Gy. Balogh 2007

Hauszmann 1911

Hegedűs 1984

Horler 1955

Horváth 1998

Joó 1968

Joó 1973

Kelényi 1976

Kelényi 2005

Komárik 1975

Koppány 1995

Krámer 1973

Krász 2014

Lipták 1983
Cs. Dobrovits Dorottya: Épitkezés a 18. századi Magyarországon. (Az uradalmak építészete.)Akadémiai Kiadó, Budapest 1983. (Mủvészettörténeti füzetek 15.)

Csorna Antal: Az óbudai Zichy-kastély kertje. Müemlékvédelem X (1966) 1. 37-40.

Dávid Ferenc: Eszterháza belső terei. Ars Hungarica XXVIII (2000) 1. 73-95.

Dávid Ferenc: A fertődi Esterházy kastély történeti helyiségkönyve: funkciók és falburkolatok. Ars Hungarica XXX (2002) 1. 237-320.

Dercsényi Balázs - Koppány Tibor: Magyar kastélyok. Officina '96 Kiadó, Budapest 1999.

G. Lászay Judit: A soponyai volt Zichy-kastély kutatása. Müemlékvédelmi Szemle 1994/1. 65-83.

Gál Tibor: Adalékok a budai királyi palota 18. századi építéstörténetéhez. Müvészettörténeti Értesitö XLI (1992) 1-4. 67-78.

Galavics Géza: Pápa. Kastélykápolna. TKM-Kiskönyvtára, Budapest 1992. (TKM 428.)

Galavics Géza: Eszterháza 18. századi ábrázolásai. Ars Hungarica XXVIII (2000) 1. 37-71.

Gerő László: A budai várpalota története 1541-től napjainkig. In: Magyarország müemléki topográfiája. 6/1. köt. Szerk.: Dercsényi Dezső. Akadémiai Kiadó, Budapest 1955. 296-300.

Gudenus János - Szentirmay László: Összetört címerek. A magyar arisztokrácia sorsa és az 1945 utáni megpróbáltatások. Mozaik, Budapest 1989.

Gyetvainé Balogh Ágnes: A zsámbéki volt Zichy-kastély építéstörténete a török hódoltság után. Épités - Épitészettudomány 35 (2007) 1. 3-63.

Hauszmann Alajos: A magyar királyi vár. Budapest 1911.

Hegedűs Ernő: Ráckeve. Savoyai-kastély. TKM-Kiskönyvtára, Budapest 1984. (TKM 186.)

Horler Miklós: Budapest müemlékei. 2. köt. Akadémiai Kiadó, Budapest 1955. (MTop VI.)

Horváth Hilda: Régvolt magyar kastélyok. Gemini Budapest Kiadó, Budapest 1998.

Joó Tibor: Az edelényi kastély. Müvészettörténeti Értesitő XVII (1968) 189-206.

Joó Tibor: Múemlékeink: a kastély, a reformárus templom, a vár. In: Sápi Vilmos (szerk.): Edelény múltjából. Edelény 1973.

Kelényi György: Franz Anton Hillebrandt 1719-1797. Akadémiai Kiadó, Budapest 1976. (Művészettörténeti füzetek 10.)

Kelényi György: A királyi udvar épitkezései Pest-Budán a XVIII. században. Budapest 2005. (Mủvészettörténeti füzetek 28.)

Komárik Dénes: A romantikus kastélyépítészet kezdetei Magyarországon. Épités- Épitészettudomány V (1975) 3-4. 431-451.

Koppány Tibor: Várak és kastélyok Magyarországon a 11-19. században. OMvH, Budapest 1995. (Kiállítási katalógus.)

Gerőné Krámer Márta: Adatok a nagycenki volt Széchenyi-kastély építéstörténetéhez. Épités- Épitészettudomány V (1973) 3-4. 479-487.

Krász Lilla: A lélek Táplálása. In: Edelényi hétköznapok. Forster Gyula Nemzeti Örökséggazdálkodási és Szolgáltató Központ, Budapest 2014.

Lipták Irén: Az óbudai v. Zichy-kastély helyreállitása. Müemlékvédelem XXVII (1983) 1. 43-55. 
M. Szilágyi 2001

Markó 2000

Mojzer 1971

Monok 2010

Néma-Smuk 2003

Németh 2005

Novák 1836.1

OMF 1985

Óhidy 2007

Örsi 1989

Pazár-Joó 1963

Péczely 1958

Peterdi 1995

Püski 2008

R.Várkonyi

Rados 1931

Rados 1939

Rados 1985

Ripka 1896

Schmeller-Kitt 1974
M. Szilágyi Kinga: A gödöllői kastélypark története - a rekonstrukció elvi szempontjai. In: Alföldy Gábor (szerk.): Királyi és hercegi kertek Magyarországon. Mágus Kiadó, Budapest 2001. 26-42.

Markó László: A magyar állam föméltóságai Szent Istvántól napjainkig. Magyar Könyvklub, Budapest 2000.

Mojzer Miklós: Torony, kupola, kollonád. Akadémiai Kiadó, Budapest 1971. (Művészettörténeti füzetek 1.)

Monok István: A magyarországi fönemesség könyves müveltsége a XVIXVII. században. Akadémiai doktori értekezés tézisfüzete, Szeged-EgerChatou 2010.

Néma Sándor - Smuk Péter: Hédervár. Száz Magyar Falu Könyvesháza Kht., Budapest 2003. (Száz magyar falu)

Németh András: Neveléstörténet. Kézirat, 2005. (http://magyar-irodalom. elte.hu/nevelestortenet/07.08.html (Utolsó megtekintés: 2019. 07. 10.)

Novák Dániel: Budavidéki utazás. Másod ízben. Hasznos mulatságok (1836) II. félév. 29-30. sz. 227-231, 235-240.

Kiemelt müemléki jelentöségü kastélyok állagmegóvási programja. OMF, 1985. 49-63.

Óhidy Viktor: Föúri lakáskultúra Magyarországon a dualizmus idöszakában. Doktori disszertáció. ELTE Bölcsészettudományi Kar, Budapest 2007. (Kézirat.) doktori.btk.elte.hu/hist/ohidy/dissz_ohidy.pdf (Utolsó megtekintés: 2019. 07. 11.)

Örsi Károly: A csákvári Esterházy-kastély kertépítészetének története. Müemlékvédelem XXXIII (1989) 4. 293-308.

Pazár Miklósné - Joó Tibor: Újabb adatok az edelényi kastély építéstörténetéhez. Müemlékvédelem VII (1963) 3. 138-144.

Péczely Piroska: A keszthelyi Festetics-kastély és belsö berendezése. K. n., Budapest 1958.

Peterdi Ede: A bicskei Batthyány-kastély. KÖZDOK Kft., Budapest 1995.

Püski Levente: Arisztokrácia a 20. századi Magyarországon. Korunk 19 (2008) 9. sz. (http://epa.oszk.hu/00400/00458/00141/puskil.html (Utolsó megtekintés: 2019. 07. 10.)

R. Várkonyi Ágnes: A társadalom a 17-18. század fordulóján. Társadalomfejlödés és országegység. Aulikus fonnemesség és új nemesi rétegek. (http:// multunk.com/index.php?title=Aulikus_f $\%$ C5\%91nemess $\%$ C3\%A9g_\% C3\%A9s_\%C3\%BAj_nemesi_r\%C3\%A9tegek (Utolsó megtekintés: 2019 . 07. 10.); Nagybirtokos osztály - arisztokrácia. (http://multunk.com/index. php?title $=$ Nagybirtokos_oszt $\% \mathrm{C} 3 \% \mathrm{~A} 11$ y_\%E2\%80\%93 arisztokr\%C3\%A1cia (Utolsó megtekintés: 2019. 07. 10.)

Rados Jenö: Magyar kastélyok. MOB és a Könyvbarátok Szövetsége, Budapest 1931.

Rados Jenő: Magyar kastélyok. Bővített második kiadás. MOB, Budapest 1939. (Magyarország mủvészeti emlékei IV.)

Rados Jenő: A ráckevei volt Savoyai-kastély mủemléki helyreállítása. Müemlékvédelem XXIX (1985) 1. 16-29.

Ripka Ferenc: Gödöllö - A királyi család otthona. Budapest 1896.

Schmeller-Kitt, Adelheid: Östrreichische Kunsttopographie. Band XL. Die Kunstdenkmäler des Politischen Bezirkes Oberwart, Anton Schroll \& Co., Wien 1974. 
Simon-Keresztessy 2002

Sisa 1980

Sisa 1981

Sisa 1985

Sisa 1994

Sisa 1997

Sisa 2000

Sisa 2004

Sisa 2007

Soós 2002

Sztárayné 2001

Tóth-Bay 2014

Varga 1997

Varga 2003

Virág 2007

Voit 1955

Voit 1964

Voit 1981

Voit 1982

Voit 1993

Ybl 1924

Ybl 1956

YblMKat.1991
Simon Zoltán - Keresztessy Csaba: A hőgyészi Apponyi-kastély építéstörténete. In: Magyar Müemlékvédelem 1991-2001. OMvH, Budapest 2002. 313-332. (Az OMvH Évkönyve XI.)

Sisa József: Adalékok a magyarországi romantikus kastélyépítészethez. Ars Hungarica VIII (1980) 1. 103-125.

Sisa Béla: Békés megye müemlékei. I. köt. Budapest 1981.

Sisa József: Gottfried Semper és Magyarország. Müvészettörténeti Értesitö XXXIV (1985) 1-2. 1-9.

Sisa József: A bicskei Batthyány-kastély és Hild János. Müvészettörténeti Értesitö XLIII (1994) 1-2. 65-70.

Sisa József: A csákvári Esterházy-kastély. Müvészettörténeti Értesitő XLVI (1997) 1-2. 1-42.

Sisa József: A nádasdladányi Nádasdy-kastély. Müvészettörténeti Értesitö XLIX (2000) 1-2. 21-53.

Sisa József: A nádasdladányi Nádasdy-kastély. Mủemlékek Állami Gondnoksága, Budapest 2004.

Sisa József: Kastélyépitészet és kastélykultúra Magyarországon. A historizmus kora. Vince Kiadó, Budapest 2007.

Soós István: Az alcsúti Habsburg-kastély tündöklése és pusztulása. Szent István Király Múzeum, Székesfehérvár 2002.

Sztárayné Kézdy Éva: Egykori arisztokrata családok leszármazottai a mai Magyarországon. PhD-értekezés, kézirat, Budapest 2001.

Tóth Áron - Bay Judit (szerk.): Edelényi Kastélysziget. Forster Gyula Nemzeti Örökséggazdálkodási és Szolgáltatási Központ, Budapest 2014.

Varga Kálmán: Grassalkovich-kastély, Gödöllö. Gödöllöi Királyi Kastélymúzeum, Gödöllő 1997. (Gödöllői kastélykönyvek I.)

Varga Kálmán: A gödöllöi kastély évszázadai. Műemlékek Állami Gondnoksága, Budapest 2003.

Virág Irén: Az arisztokrácia neveltetése Magyarországon (1790-1848). PhD-értekezés, kézirat, Budapest 2007.

Voit Pál: A budai várpalota interieurjei. In: Budapest régiségei. Szerk.: Gerevich László. Képzőművészeti Alap Kiadóvállalata, Budapest 1955. (A Budapesti Történeti Múzeum Évkönyve XVI.)

Voit Pál: Beszámoló az OMF távlati kutatási tervéhez kapcsolódó levéltári munkáról. In: Magyar müemlékvédelem 1959-60. Akadémiai Kiadó, Budapest 1964. 254-261.

Voit Pál: Barokk tervek és vázlatok 1650-1760. Szerk.: Buzási Enikő. Magyar Nemzeti Galéria, Budapest 1981. (Kiállítási katalógus.)

Voit Pál: Franz Anton Pilgram 1699-1761. Akadémiai Kiadó, Budapest 1982.

Voit Pál: Régi magyar otthonok. (Az 1943-as kiadás bővített változata.) Szerk.: Sturcz János. Balassi Kiadó, Budapest 1993.

Ybl Ervin: Savoyai Jenö herceg ráckevei kastélya. Budapest 1924. (Országos Szépművészeti Múzeum Évkönyvei.)

Ybl Ervin: Ybl Miklós. Képzőmủvészeti Alap Kiadóvállalata, Budapest 1956.

Ybl Miklós épitész 1814-1891. Szerk.: Farbaky Péter, Kemény Mária. [Budapest], Hild-Ybl Alapítvány, 1991. (Kiállítási Katalógus.) 


\section{ÁBRAJEGYZÉK}

1. ábra. A reprezentatív nyilvános és félig nyilvános házi kápolnák példái a 18-19. századból:

a) Nagybodok: Báró Stummer Sándor kastélyának kápolnája, belsö kép. Archív fotó. Közli: SzU VI (1901) okt. 15. 8.

b) Galgóc: A vár kápolnájának belső képe. Archív fotó. Közli: VU LIX (1912) jan. 7. 11. 4. kép

c) Brogyán: Oldenburg Natália hercegné kastélykápolnája, belső kép. Archív fotó. Közli: $\mathrm{Sz} U$ VI (1901) okt. 15. 5.

d) Muraszombat: Gróf Szapáry László kastélyának kápolnája, belső kép. Archív fotó. Klösz György felvétele, 1895-1899 között. BFL XV.19.d.1.12.203.

e) Füles: Gróf Zichy Jakab kastélyának kápolnája, belsö kép. Archív fotó. Klösz György felvétele, 1895-1899 között. BFL XV.19.d.1.11.183.

f) Magyarbél: Xivkovich Emilné Pilta Erzsébet kastélyának kápolnája, belsö kép. Archív fotó. Közli: $S z U$ VI (1901) szept. 15. 7.

g) Kékkő: Gróf Almásy Dénesné kastélyának kápolnája, belső kép. Archív fotó. Közli: $S z U$ XII (1907) szept. 15. 5.

h) Zsigmondháza: Herceg Hohenlohe Clodwigné kastélyának kápolnája, belső kép. Archív fotó. Közli: $S z U$ VII (1902) szept. 15. 5.

i) Szentantal: Coburg Fülöp herceg kastélyának kápolnája, belső kép. Archív fotó. Közli: $M N$ $\mathrm{V}(1900)$ jan. 5.

j) Petőfalu: Blundell-Uzovics Ludovica kastélyának kápolnája, belső kép. Archív fotó. Közli: SzU VI (1901) aug. 15. 8.

k) Nagyzáblat: Szabolcsi Polyák Béla kastélyának kápolnája, belső kép. Archív fotó. Közli: $S z U$ VII (1902) okt. 15. 11.

l) Sopronhorpács: A kastély kápolnája ünnepi díszitéssel, belső kép. Archív fotó. Közli: $S z U$ VIII (1903) jan. 15. 4.

m) Alsókorompa: Gróf Chotek Rudolf kastélyának kápolnája, belső kép. Archív fotó. Közli: $\mathrm{Sz} U$ V (1900) dec. 8.

2. ábra. A fő́ri magánkápolnák példái a 18-19. századból:

a) Féltorony: Habsburg-Lotharingiai Frigyes föherceg kastélyának kápolnája, belsö kép. Archív fotó. Közli: $S z U$ VII (1902) dec. 15. 12.

b) Osgyán: Báró Luzsénszky Henrik kastélyának kápolnája, belső kép. Archív fotó. Közli: SzU XI (1906) júl. 31. 9.

c) Köpcsény: Dr. gróf Batthyány László kastélyának kápolnája, belsö kép. Archív fotó. Közli: $\mathrm{Sz} U \mathrm{XI}$ (1906) dec. 15. 14.

d) Lajtaújfalu: Gróf Batthyány Tivadar kastélyának kápolnája, belsö kép. Archív fotó. Közli: $S z U$ IX (1904) júl. 31. 5.

e) Szepesmindszent: Gróf Csáky Albin kastélyának kápolnája, belső kép. Archív fotó. Közli: $\mathrm{Sz} U$ XII (1907) szept. 15. 11.

f) Csombárd: Báró Pongrátz Matild kúriájának kápolnája, belső kép. Archív fotó. Közli: $S z U$ VI (1901) jún. 30. 15.

g) Parádfürdő: A kastély kápolnája. Képes levelezőlap a szerző gyüjteményéből

h) Nagykároly: A kápolna belső képe. Képes levelezőlap. Kiadó: Csókás László. IM ltsz.: MLT 1701/108. Közli: Horváth 1998. 184. 130. kép

i) Nógrádgárdony: Gróf Mailáth Géza kastélyának kápolnája, belső kép. Archív fotó. Közli: $\mathrm{Sz} U \mathrm{X}$ (1905) aug. 15. 8.

3. ábra. A magánkápolnák ábrázolásának példái a 18-20. századból: Vedrőd, a kastély átalakítási tervrészlete a 18. századból:

a) alaprajzok: Vedrőd: a kastély földszinti és emeleti kéziratos, színezett alaprajza. Sign. nélk. [Geel, Matthias.] MNL-OL S17. No.137/1. [P 707 Fasc. 26. et B. No 30.] 
b) metszet: Vedrőd : a kastély földszinti és emeleti kéziratos, színezett homlokzatai és metszetei. Felirata: „Prospect des herrschaftlichen Schlosses Wödrit”. Sign.: Geel, Matthias. MNL-OL S17. No.137/2. [P 707 Fasc. 26. et B. No 30.]

c) Oroszvár, a kastély átalakításának részletrajza a 19. századból: A kastély földszinti átalakitási alaprajza, 1843. MNL-OL T 17 4. 35-38. Közli: Komárik 1975. 439. 6. kép

d) Nagyláng, a kastély 1984. évi átalakításának rajzrészlete a kápolna ábrázolásával: Földszinti alaprajz 1984-ben. Szűcs Endre, Koppány Tiborné rajza. Közli: G. Lászay 1994. 66.

4. ábra. A föúri házikápolnák elhelyezésének és funkcionális kapcsolatainak tipológiája a 18-19. században. A szerző elemzése

5. ábra. A nyilvános házikápolnák példái:

a) Zsámbék: A zsámbéki kastély földszinti és emeleti alaprajza. Hamon János Mihály 1774 körüli rajza. MNL-OL T-1. N²11/a-b. Részletét közli: Mtop.V. 507-508.

b) Edelény: Az edelényi kastély földszintjének és emeletének felmérése Esterházy István számára 1763-1764-böl. Franz Anton Dvorzaczky rajza. BAZmL Acta iudicialia, Spec. VII. Fasc. Com. I. No. 70. Közli: Pazár-Joó 1963. 140. 2-3. kép; Joó 1968. 191. 2-3. kép; Joó 1973. 155.

6. ábra. Gödöllö: a kastélykápolna

a) alaprajzai: A kastély földszinti alaprajza 1870-1871. Kirscher Ferdinand (?) terve. Felirata fent középen: „Schloss Gödöllő Ebene erde”. MMA-MDK tervtár rajz ltsz.: 50986. Közli: Varga 1997. 37; M. Szilágyi 2001. 219. 12. kép; Varga 2003. 72; A kastély alaprajza 1867 után. Felirata: „A gödöllői királyi kastély 1. emeleti alaprajza”. MMA-MDK tervtár rajz ltsz.: 51015 .

b) urasági oratórium karzata: Archív fotó, 1910 előtt. Közli: Borovszky.Pest-Pilis 77. 1. kép c) belső látképe: Archív fotó. Erdélyi Mór fényképfelvétele. Közli: Ripka 1896

7. ábra. A budai királyi palota kápolnái: Zsigmond-kápolna:

a) alaprajzi tervezetek: A palota pince, földszinti, elsö és második emeleti alaprajza. Franz Anton Hillebrandt, 1770. Elpusztult. Fotókópiáját közli: Kelényi 1976. 222-223. kép; Gál 1992. 75. 15. ábra

b) keresztmetszet: A palota keresztmetszete és homlokzata. Nedeczky Pál másolata ismeretlen szerző rajza után, 1779. Piarista Levéltár, Budapest. Közli: Gál 1992. 75. 14. ábra; Kelényi 2005. 34. kép

c) hosszmetszet: A Szent Zsigmond-kápolna hosszmetszete. Sign. „I.H.” Közli: Kelényi 1976. 26. kép; Kelényi 2005. 30. kép

d) megvalósult alaprajz: A palota első emeletének alaprajza. Weiss-Neuwirth-Holzer. Közli: Gerő 1955. 291. 212. ábra

e) Szent Jobb-kápolna metszete: Kéziratos. [Franz Anton Hillebrandt] MNL-OL T14. No.1/28.

8. ábra. A budai királyi palota kápolnái: Zsigmond-kápolna:

a) alaprajzok: A kibővített királyi palota földszinti, első emeleti, második emeleti alaprajza. Közli: Hauszmann 1911. 22-23, 25.

b) belső kép az oltárral: A Szent Zsigmond-, később Szent István-kápolna belső képe. Az ún. Szent István-terem. Archív fotó. Közli: VU L (1903) szept. 6. 590.

c) az új Szent Jobb-kápolna oltára: Archív fotó. Közli: Hauszmann 1911. 53.

9. ábra. A nyilvános házikápolnák példái:

a) az ún. vízi kastély kápolnájának alaprajzai: Vízi kastély földszinti alaprajza, Franz Anton Pilgram mủve (?). Színezett, lavírozott tusrajz. MMA MDK 1tsz.: 72.020.10. Közli: Voit 1982. 54-55, 166. 130. kép; Vizi kastély emeleti alaprajza, Franz Anton Pilgram müve (?). Színezett, lavírozott tusrajz. MMA MDK. Közli: Voit 1982. 275. 211. ábra.

Gyula, a tervezett kastély kápolnájának 
b) metszete: A gyulai Harruckern-kastély bövitési terve. Keresztmetszet a kápolnán keresztül. Franz Anton Hillebrandt, 1760. Zölddel, barnával, rózsaszínnel színezett, lavírozott tus. $64,3 \times 50$ cm. MNL OL T 20 N57/10. Közli: Voit 1981. 47, 148. 106/j. kép

c) alaprajzai: A gyulai Harruckern-kastély bövitési terve. Földszinti alaprajz a régi falakkal. Franz Anton Hillebrandt, 1760. Zölddel, barnával, rózsaszínnel színezett, lavírozott tus. 50,7x141,5 cm. MNL-OL T 20 N57/4. Közli: Voit 1981. 47, 145. 106/d. kép; Sisa 1981. I. 167; A gyulai Harruckern-kastély bövitési terve. Emeleti alaprajz a régi falakkal. Franz Anton Hillebrandt, 1760. Zölddel, barnával, rózsaszínnel színezett, lavírozott tus. 50,6x140,5 cm. MNL-OL T 20 No57/5. Közli: Voit 1981. 47, 146. 106/e. kép

10. ábra. Monok: a kastélykápolna

a) alaprajzai: Andrássy György gróf kastélya. Földszinti alaprajz az átalakitásokkal. Kéziratos. 1840 körül. Felirat: Zu Ebener Erde, Nro. XV. Ik Szám Zeman Alajos. BFL XV.17.f.331.b - 17/13. Közli: Ybl 1956. 183.; Emeleti alaprajz az átalakitásokkal. Kéziratos. 1840. körül. Felirat: Erster Stock, Nro. XX-ik Szám Zeman Alajos. BFL XV.17.f.331.b 17/16, 17/18. Közli: Ybl 1956. 183.

b) belső képei (oratórium-karzat és az oltár): Fényképfelvételek a szerző gyüjteményéből

11. ábra. Kiscenk: a)-c) a kastély kápolnájának alaprajzi változatai: Franz Anton Pilgram terve Széchényi Antal kiscenki kastélyára, 1750 k. Rózsaszínnel, szürkével lavírozott tus. 482 x $620 \mathrm{~mm}$. Felirata fent kartusban: „Haübt Rann des biano Nobile oder obern Stocks. Explication...” Sign.: „Fr. Ant. Pilgram. NÖ. Land Bau Maister.” Én. MNL-OL T21 2. Közli: Voit 1964. 254. 241. kép; Voit 1981. 154. 113. kép; Voit 1993. 264. 253. kép; Hefele Menyhért (?) terve Széchényi Ferenc kiscenki kastélyának bövitésére, 1791. Sign. Jobbra lent: „Aurei...” MNL-OL T21 º13. Közli: Voit 1964. 256. 243. kép; A kastélykápolna, a sekrestye és a káplánszoba, 1836. Részlet a föépület alaprajzáról. (https://sopronimuzeum. hu/2014/12/09/a-szechenyi-csalad-nagycenki-kastelykapolnaja/ (Utolsó megtekintés: 2020. 03. 21.)

12. ábra. A magánkápolnák példái: Hédervár:

a) a kápolna alaprajzai: Földszinti és emeleti alaprajz. Közli: Rados 1931. 215. 209-210. ábra, Rados 1939. 34.

b) belső képe: Archív fotó. Közli: Néma-Smuk 2003

c) Óbuda: Az óbudai volt Zichy-kastély alaprajzai és metszetei. Gföller Jakab felvételi rajza 1777-ben. MNL-OL T 1. №167/1. Közli: Horler 1955. 340. 272. kép; Csorna 1966. 38. 3. kép; Lipták 1983. 44. 2. kép

13. ábra. Eszterháza: a)-b) a kápolna alaprajzai: Esterházy Miklós herceg eszterházai kastélyának alaprajza, 1784 körül. Nicolaus Jacoby rajza után Marcus Weinman rézmetszete, 1784. Papír, 483x359 mm. Publ.: Niemetz Primitivus: „Beschreibung des Hochfürstlichen Schlosses Esterhaz im Königreiche Ungern” Nr. 2. Közli: Koppány 1995. 34. 40. kép; Galavics 2000. 59, 66. 20. kép.; Földszinti alaprajz. Közli: Rados 1931. 224. 222. ábra, Rados 1939. 52.

14. ábra. A magánkápolnák példái:

a) Hőgyész: Apponyi Géza kastélyának kápolnája, belső kép. Archív fotó. Közli: $S z U$ VI (1901) máj. 31. 6.

b) Mosdós: Örgróf Pallavicini Ede kastélyának kápolnája, belső kép. Archív fotó. Közli: $S z U$ XIII (1908) jún. 15. 7.

15. ábra. Magánkápolnák példái:

a) Ráckeve: Földszinti alaprajz. Közli: Rados 1931. 218. 217. ábra; Rados 1939. 40.

Pápa: b) a kápolna alaprajza

c) belső képe: Kápolna 1926-ban. Archív fotó. Közli: Galavics 1992. 3. 3. kép

16. ábra. Magánkápolnák példái:

a) Alcsút: A kastély felvételi terve, emeleti alaprajz. Kéziratos. 1871-1872. [Ybl Miklós] BFL - XV.17.f.331.b - 1/13. Közli: Ybl 1956. 57; YblMKat.1991. 245-246. 
b) Csákvár: Esterházy János csákvári kastélyának Fellner Jakab-féle alaptervének másolata. Földszinti alaprajz. Gött Antal, 1798. MNL-OL T-20 º 86. Közli: Voit 1964. 259; Örsi 1989. 294. 1. kép; Sisa 1997. 2. 3. kép

c) Fehérvárcsurgó: A földszinti 1977. évi felmérési alaprajza. Közli: OMF 1985. 60.

17. ábra. Nagyhörcsökpuszta:

a) a kastélykápolna tervezett helyén lévő helyiségek az új funkció ráirásával: A kastély földszintjének átalakitási terve késöbbi ceruzás berajzolásokkal. BFL XV. 331 14/25.

b) kézrajzi vázlat: Földszinti alaprajz átalakitásának vázlata. BFL XV. 331 14/6.

c) első tervváltozat a kastélykápolna kialakítására: A földszint átalakításának vázlatterve. Utólagos felirata ceruzával: „Rez de Chausée”. BFL XV. 331 14/26.

d) tisztázott alaprajz: A kastély felmérési alaprajza, földszint. Felirata: „Grundplan des Schlosses im jetzigen zustande" ETH-IGTA Archiv für Moderne Schweizer Architektur: Semper 20-189-1-1 1870. Közli: Sisa 1985. 2. 2. kép

e) a kápolna elhelyezésének meg nem valósult tervváltozata. Közli: Sisa 1985. 3. 3. kép

18. ábra. Nádasdladány:

a) a kápolna alaprajza: Nádasdy Ferenc új kastélyának terve, földszint. 1872. Felirata: „Plan des Schlosses Nádasdladány des Herrn Grafen Franz Nádasdy. Grundriss von Parterre” MNL-OL T-5 N 202. Közli: Sisa 1980. 46. kép; Sisa 2000. 24. 3. kép; Sisa 2004. 37. 21. kép

b) a kápolna belső képe: Kápolna az 1930-as években. Archív fotó. MMA-MDK Fotótár 23.368. Közli: Bugár-Mészáros 1997. 14. kép; Sisa 2000 38. 29. kép; Sisa 2004. 60. 46. kép

19. ábra. Alcsút:

a) az új kápolna belső látképe: Kápolna. Archív fotó. Közli: BpLáLa VI (1893) ápr.-máj. 16.

b) az oltár: Fényképfelvétel a szerző gyüjteményéből

c) a csarnoktér belső képe: Fényképfelvétel a szerző gyüjteményéből

20. ábra. Bicske: a) a régi kápolna alaprajza: A kastély és a szomszédos gazdasági épületek földszinti alaprajza. Kéziratos. 1785 körül. MNL-OL T 4 N 35. Közli: Sisa 1994. 67. 2. kép

b) az új kápolna alaprajza: A bicskei kastély elsö emeleti alaprajza. Közli: Sisa 1994. 67. 3. kép; Peterdi 1995. 40. 24. kép; változatát közli: Rados 1939. 57.

c) az új kápolna belső képe: Archív fotó. Közli: Peterdi 1995. 44. 26. kép

21. ábra. Keszthely: a) a kápolna alaprajza: Festetics György-korabeli épület felmérése helyiségszámozással. Földszinti alaprajz. Szignó nélkül. Felirata: „Grundriss Keszthelyer Schlosses im ietzigen Stande. 1812." MNL-OL T-3 N³33.

b) belső képe: A kápolna képe. Klösz György fényképfelvétele, 1896 körül. BFL XI. 196 1674. 11/135. Közli: Baji-Csorba 1994. 180.

22. ábra. Bajna: a) a kápolna alaprajza: Földszinti alaprajz. Közli: Rados 1931. 230. 232. ábra; Rados 1939. 64.

b) belső képe a restaurálás előtt: Fényképfelvétel a szerző gyűjteményéből

c) kápolna a restaurálás idején: Fényképfelvétel a szerző gyüjteményéből

23. ábra. Magánkápolnák példái: Fót:

a) a kápolna tervezett alaprajza: Fót, a kastély alaprajzi változata. Sign. „PÁ. YM.” (Pollack Ágoston - Ybl Miklós) BFL XV. 331 10/2. Közli: Ybl 1956. 11. kép

b) a megvalósult kápolna belső képe: Házi kápolna. Archív fotó. Károlyi László gróf albumából.

c) Vasvörösvár, a kápolna alaprajza: A kastély földszinti alaprajza 1974 elött. Közli: Schmeller-Kitt 1974. 474. ábra

24. ábra. Ókígyós:

a) a kápolna tervezett alaprajzi ábrázolása: Földszinti alaprajz korai tervváltozata Ybl Miklós épitésztöl. Rajzl., sz.tus, akv., temp.; 350 x 800 mm BFL XV. 331. 144/2. Közli: YblMKat.1991 268. Kat. 78.1.1. 
b) a kápolna megvalósult elhelyezésének helyszínrajza: A kastély és a konyhaépület helyszínrajza az elölépcsőkkel. Alaprajz. Rajzl., tus, sz.tus; 500 x 620 mm BFL XV. 331 20/14.

c) belső képe: Gróf Wenckheim Frigyes kastélyának kápolnája. Közli: SzU VII (1902) aug. 31. 10.

25. ábra. Az Egyetem utcai Károlyi-palota kápolnája:

a) alaprajz: A volt Károlyi-palota jelenlegi alaprajza. Rajz a szerző gyüjteményéből

b) belső kép: Kápolna. Archív fotó. Közli: VU LIX (1912) márc. 24. 231.

26. ábra. Kápolnasorsok a II. világháború után: Budavár:

a) belső kép az ostrom után: Archív fotó a szerző gyüjteményéből

b) belső kép a romeltakarítást követően: Archív fotó a szerző gyüjteményéből

c) Nagycenk: Archív fotó a szerző gyüjteményéből

d) Edelény: Földszinti alaprajz. Közli: Rados 1931. 219. 219. ábra; Rados 1939. 42.

27. ábra. Malacka, a kastélykápolna

a) archív képe: Archív fotó a szerző gyüjteményéből

b)-d) feltárásának állapotfotói: Archív fotók a szerző gyűjteményéből

e)-f) a kápolna belső terének helyreállított egysége: Fényképfelvételek a szerző gyüjteményéböl

28. ábra. Helyreállított kastélykápolnák:

a) Körmend: Fényképfelvétel a szerző gyüjteményéből

b) Nagycenk: Fényképfelvétel a szerző gyüjteményéböl

c)-f) Edelény: Fényképfelvételek a feltárás során és a rekonstrukciót követően. Közli: TóthBay 2014. 58, 92-93.

29. ábra. Helyreállított kastélykápolnák:

a) Hőgyész: Fényképfelvétel a szerző gyüjteményéből

b) Keszthely: Fényképfelvétel a szerző gyüjteményéből

c) Eszterháza: Fényképfelvétel a szerző gyüjteményéböl

d) Fehérvárcsurgó: Fényképfelvétel a szerző gyüjteményéből

e) Pápa: Fényképfelvétel a szerző gyüjteményéből

\section{RÖVIDÍTÉSJEGYZÉK}

BAZmL

BFL

BpLáLa

IM

MMA MDK

$M N$

MNL-OL

MTop

$\mathrm{Sz} U$

TKM

VU
Magyar Nemzeti Levéltár Borsod-Abaúj-Zemplén Megyei Levéltára, Miskolc

Budapest Főváros Levéltára, Budapest

Budapesti Látogatók Lapja

Iparművészeti Múzeum

Magyar Mủvészeti Akadémia, Magyar Építészeti Múzeum és Mủemlékvédelmi Dokumentációs Központ, Budapest

Magyarország és a Nagyvilág

Magyar Nemzeti Levéltár Országos Levéltára, Budapest

Magyarország Müemléki Topográfíja

Szalon Újság

Tájak Korok Múzeumok Kiskönyvtára

Vasárnapi Ujság 


\title{
THE NOBLE HOME CHAPELS OF HUNGARY IN THE $18^{\mathrm{TH}}$ AND $19^{\mathrm{TH}}$ CENTURIES
}

\begin{abstract}
Summary
Castles, palaces, mansions, fortresses - namely the noble households - are elements of the profane architectural genre primarily, but their functional diversity and complexity are well represented by the fact that most of them have sacred functions as well. The home chapel of the secular noble households can be considered as the most important venue for religious practice at home, which was a typical symbol of the noble religiousness until the mid- $19^{\text {th }}$ century. The spatial composition of the home chapels was specialized to a simplified version of the liturgy. Nevertheless, the joint presence of the nobility and the common folk resulted in a functionally differentiated, articulated space form. The $18^{\text {th }}$-century examples of vaulted halls with high ceilings and galleries could have been based on a late-medieval tradition, but they were suitable for public liturgy as well through their direct courtyard entrance. The disposition of the home chapels was very various in the $18^{\text {th }}$ and $19^{\text {th }}$ centuries. As for the pre- 1850 examples their spatial connection within the building was provided by the noble oratorial gallery, which was accessible from the male apartments typically, regardless of its layout in ground-floor or upstairs. At the same time there were also some examples of a chapel on the female side, and between the two apartments as well. In addition to the generous, attractive public chapels, also smaller private chapels were often built within the apartments at that time. From the middle of the $19^{\text {th }}$ century the traditional functionality of the home chapels was preserved, but it became typical that the location of the chapels was rather away from the owner apartments, in some cases connected to the guest apartments at the end of the building wings, which meant a "peripheral" disposition to the primary paths of usage. Besides, there are examples to an emphatic connection to the monumental group of central social rooms.
\end{abstract}

Keywords: castle, palace, noble household, home chapel, private chapel, oratorio, function, disposition, Baroque, historicism

\section{DIE EDLEN HAUSKAPELLEN VON UNGARN IN 18-19. JAHRHUNDERTEN}

\section{Zusammenfassung}

Schlösser, Paläste, Herrenhäuser, Burgen - nämlich die Adelswohnsitze - sind in erster Linie Elemente des profanen Architekturgenres, aber ihre funktionale Vielfalt und Komplexität wird dadurch entsprechend repräsentiert, dass die meisten von ihnen auch heilige Funktionen haben. Die Hauskapelle der säkularen Adelswohnsitze kann als wichtigster Platz der Religionsausübung zu Hause angesehen werden, der bis Mitte des 19. Jahrhunderts ein typisches Symbol für die edle Religiosität war. Die räumliche Struktur der Hauskapellen war auf eine vereinfachte Version der Liturgie spezialisiert. Dennoch führte das Zusammensein von Adel und Volk zu einer funktional differenzierten, gegliederten Raumform. Die Beispiele aus dem 18. Jahrhundert können einer spätmittelalterlichen Tradition - Gewölbesäle mit hohen Decken und Galerien - entsprungen sein, aber sie waren auch für die öffentliche Liturgie durch ihren direkten Eingang vom Innenhof geeignet. In 18. und 19. Jahrhunderten war die Anordnung der Hauskapellen sehr unterschiedlich. Was die Beispiele aus der Zeit vor 1850 betrifft, wurde ihre räumliche Verbindung innerhalb des Gebäudes durch die edle Oratorialgalerie, die von dem Männerapartment aus zugänglich war - unabhängig von seiner Anordnung im Erdgeschoss oder im Obergeschoss, ermöglicht. Ausserdem gab es einige Beispiele für eine Kapelle sowohl auf der weiblichen Seite als auch zwischen den beiden Apartments. Neben den großzügigen und attraktiven öffentlichen Kapellen wurden auch 
kleinere Privatkapellen innerhalb des Apartments zu dieser Zeit häufig errichtet. Ab der Mitte des 19. Jahrhunderts blieb die traditionelle Funktionalität der Hauskapellen erhalten, aber es war typisch, dass die Lage der Kapellen eher ferner von den Apartments der Eigentümer lag, in einigen Fällen verbunden mit den Gästeapartments am Ende eines Gebäudeflügels. Das bedeutete eine ,periphere“ Anordnung zu den primären Benutzungswegen. Daneben gibt es Beispiele für eine betonte Verbindung zur monumentalen Gruppe zentraler Sozialräume.

Schlüsselwörter: Schloss, Palais, edler Wohnsitz, Hauskapelle, private Kapelle, Oratorie, Funktion, Disposition, Barock, Historismus

Open Access nyilatkozat: A cikk a Creative Commons Attribution 4.0 International License (https://creativecommons.org/licenses/by/4.0) feltételei szerint publikált Open Access közlemény, melynek szellemében a cikk bármilyen médiumban szabadon felhasználható, megosztható és újraközölhető, feltéve, hogy az eredeti szerző és a közlés helye, illetve a CC License linkje és az esetlegesen végrehajtott módosítások feltüntetésre kerülnek. (SID_1)

Beérkezett: 2020. január 14. Elfogadva: 2020. március 19.

Online First megjelenése: 2020. június 3. 